\title{
15. DISTRIBUTION AND CHEMISTRY OF PHILLIPSITE, CLINOPTILOLITE, AND ASSOCIATED ZEOLITES AT DSDP SITES 382, 385, AND 386 IN THE WESTERN NORTH ATLANTIC
}

Robert L. Houghton, Department of Geology and Geophysics, Woods Hole Oceanographic Institution, Woods Hole, Massachusetts and Department of Earth and Planetary Science, Massachusetts Institute of Technology, Cambridge, Massachusetts

Peter Rothe, Abteilung für Geologie, Geographisches Institut der Universität Mannheim, D-6800 Mannheim, Schloss, West Germany, and Institut für Sedimentforschung der Universität Heidelberg, D-6900 Heidelberg, Federal Republic of Germany and

Jon S. Galehouse, Department of Geology, San Francisco State University, San Francisco, California

\begin{abstract}
Sediment samples obtained by deep-sea drilling at DSDP Sites 382,385 , and 386 in the western North Atlantic contain limited concentrations of phillipsite and clinoptilolite, the concentrations of which are controlled apparently by bulk sediment content. Quantitative estimates of zeolite mineral concentrations determined by $\mathrm{X}$-ray diffraction reveal that phillipsite is the dominant zeolite in volcanogenic and montmorillonite-rich sediments. Zeolite minerals in siliceous and feldspathic sediments are dominated by clinoptilolite. High carbonate content appears to promote zeolite dissolution. As volcanogenic sediments dominate the sedimentary section on seamounts as at Sites 382 and 385 , phillipsite tends to be the dominant zeolite mineral appearing on such topographic features. The remaining North Atlantic reflects the high silica and alkali feldspar content of the sea-floor sediments, as clinoptilolite dominates the zeolites of these beds.

The major element composition of selected zeolites reflects their mineralogy, but not the environment of their genesis. No systematic chemical variation is observed among analyses of a zeolite mineral from various types of sedimentary beds, save a tendency for sedimentary phillipsites to be slightly more silicic and potassic than their volcanogenic counterparts. Trace elements show greater variability, but insufficient data are available to evaluate their variation.
\end{abstract}

\section{INTRODUCTION}

Zeolites are hydrated aluminosilicates of the alkali metals and alkaline earths that can be visualized as hydrated equivalents of the feldspar series. Although zeolites have been recognized as a distinct mineral group since 1756 and have been employed as natural sieves in a variety of industrial uses for centuries, their potential importance as environmental indicators has only recently been perceived.

Whereas the mechanisms of zeolite formation are not clearly understood, several distinctive types of zeolite-bearing marine deposits have been recognized, including (1) deposits formed by low-grade burial metamorphism or hydrothermal alteration of sea-floor basalt (Coombs, 1954; Walker, 1960a, b; Hay, 1966), (2) deposits formed from volcanic debris or clay minerals (Ross, 1928, 1941; Bramlette and Posjnak,
1933; Regnier, 1960; Hay, 1966), and (3) deposits probably formed authigenically and displaying no evidence of volcanic precursors (Murray and Renard, 1891; Coombs et al., 1959; Shepard, 1973). Zeolites of the first two types probably inherit their tektosilicate framework from their parent silicates (e.g., feldspars, feldspathoids, montmorillonite, igneous glass, ....); but the exchangeable cations, such as $\mathrm{Na}^{+}, \mathrm{K}^{+}, \mathrm{Ca}^{2+}$, and $\mathrm{Ba}^{2+}$, and trapped trace metals, such as $\mathrm{Pb}, \mathrm{Cu}$, $\mathrm{Ni}$, and $\mathrm{Co}$, which inhabit the group's honeycomb structures, are derived partially from the environment of crystal growth (Arrhenius, 1963; Shepard, 1973). These elements may serve as environmental "tags" once their character and distribution in zeolites have been studied fully. Considerable question remains as to whether even authigenic zeolites derive their framework from the dissolved silica and alumina of seawater. Bonatti (1963) has concluded that this mode 
of origin is unlikely and that clay minerals in the sediment probably serve as progenitors for "authigenic" zeolites.

The phillipsite $\left[(1 / 2 \mathrm{Ca}, \mathrm{Na}, \mathrm{K})_{5} \mathrm{Al}_{5} \mathrm{Si}_{11} \cdot 10 \mathrm{H}_{2} \mathrm{O}\right.$; ideal formula of Steinfink, 1962]-harmotome $\left[\mathrm{Ba}\left(\mathrm{Al}_{2} \mathrm{Si}_{6} \mathrm{O}_{16}\right)\right.$ - $6 \mathrm{H}_{2} \mathrm{O}$; Strunz, 1970] series and clinoptilolite $\left[(\mathrm{Na}, \mathrm{K})_{4} \mathrm{CaAl}_{6} \mathrm{Si}_{30} \mathrm{O}_{72} \cdot 24 \mathrm{H}_{2} \mathrm{O}\right.$; Sheppard, in Stonecipher, 1976] are the two most abundant zeolites in marine sediments. In the Pacific Ocean, phillipsite is the most important sedimentary zeolite (Bonatti, 1963). It occurs commonly in association with basic volcanic glass. In the South Pacific where significant amounts of igneous silicates are absent, however, the tests of opalsecreting organisms contain appreciable clinoptilolite (Arrhenius, 1963). Goodell (1965) believes the silica is supplied by dissolution of these tests. In the Atlantic, clinoptilolite is generally found to dominate the zeolite component of the sedimentary section (Turekian, 1965; Stonecipher, 1976). The few reported occurrences of phillipsite in the North Atlantic (Young, 1939; Dekeyser, 1958; Biscaye, 1964) are associated with volcanic islands and seamounts, although a genetic relationship to this environment has not been firmly established.

Using data from the Deep-Sea Drilling Project Initial Reports, Stonecipher (1976) has demonstrated a general correlation between phillipsite occurrences and argillaceous, volcanic, and/or siliceous sediments, low sedimentation rates $(<5 \mathrm{~m} / \mathrm{m} . \mathrm{y}$.), shallow depth of burial, and young geologic age (Miocene or younger). Conversely, clinoptilolite is found in association with calcareous sediments, indicators of abundant silica such as disordered cristobalite, moderate to high sedimentation rates ( $>5 \mathrm{~m} / \mathrm{m} . \mathrm{y}$.$) , and greater age. These varia-$ tions in the distributions of phillipsite and clinoptilolite suggest each of the zeolite minerals should be treated separately in any discussion of their origin.

The problems to be resolved before the origins of marine zeolites are fully understood thus remain largely unchanged since the summaries of Sudo and Matsuoka (1959), Coombs et al. (1959), and Mumpton (1960). The scarcity of good data on the distribution and chemistry of individual zeolites continues to be a major stumbling block. We hope that this paper will supply some of the missing pieces and help others interested in zeolite origins toward resolution of the phillipsite and clinoptilolite problems.

\section{EXPERIMENTAL PROCEDURES}

During routine shipboard core description, estimates of zeolite concentration and distribution were made from smear slides. Ten cubic centimeter samples were taken for X-ray mineralogy analysis at regular intervals (at least one every $9 \mathrm{~m}$ of core) and at any lithologic changes. Splits of these samples were also used for the other analyses discussed here. The bulk of the quantitative X-ray mineralogy was done at the University of Heidelberg using a Philips model PW1310 scanning $\mathrm{X}$-ray diffractometer. Details of the procedures employed are reported in a separate paper (Koch and Rothe, this volume). Additional samples were obtained from Site 385 and analyzed by a like procedure using a
Picker X-ray diffractometer at M.I.T. and in-house standards of phillipsite and clinoptilolite from Laki, Iceland. The M.I.T. results are appropriately labeled in the accompanying data tables.

Samples suggesting concentrations of phillipsite or clinoptilolite were selected for additional examination using a Cambridge model S4-10 scanning electron microscope at the University of Heidelberg. Sediment samples were disaggregated and attached to the specimen holder with colloidal silver and then gold sputtered. The SEM was operated at $20 \mathrm{kv}$. Crystals selected during SEM study were also examined by nondispersive $\mathrm{X}$-ray spectroscopy to obtain qualitative elemental analyses.

Pure zeolite concentrations were prepared at M.I.T. using sonic sieving, index of refraction, heavy liquid, and microscopic techniques. Before final density separation, the samples were treated for three minutes in a 5 per cent solution of cold $\mathrm{HCl}$, after which they were cleaned in distilled water with an ultrasonic cleaner. The procedure was repeated when necessary, and final separation was performed by hand-picking. Selected crystals were then mounted in epoxy, polished, and carbon-coated for analysis with the PDP 11 computerautomated electron microprobe at M.I.T. At least six replicate analyses per crystal were used to check precision. Accuracy, checked by comparison of results for a heulandite from Hawaii with wet chemical analyses of B. Eakle, was good to excellent. $\mathrm{H}_{2} \mathrm{O}$ and $\mathrm{CO}_{2}$ were determined on a Beckman automated gas chromatograph at M.I.T.

\section{DISTRIBUTION}

Three drill sites from Leg 43 in the western North Atlantic were studied to determine the nature and distribution of zeolites. Two sites (382 and 385) are on seamounts and one (Site 386) on normal sea floor. Bulk X-ray diffraction (XRD) results for each site are presented in Table 1. Figures 1,6 , and 8 show the downcore distribution of the significant zeolites at Sites 382,385 , and 386 , respectively.

\section{Site 382-Nashville Seamount}

The stratigraphically highest lithologic unit recovered at Site 382 on the eastern flank of Nashville Seamount (see Site 382 Report) consists of Quaternary and upper Pliocene turbidite deposits about 232 meters thick. The range of mineral compositions displayed by this unit is presented in Table 1. Calcite concentrations average 8 per cent. Of the major potential zeolite progenitors, feldspars are the most abundant, composing about 15 per cent of the sediment. Indicators of a volcanic contribution are lacking, as expressed by the extremely low proportion of montmorillonite in the clay mineral fraction. Even the most clay-rich beds of this unit appear to be barren of zeolites (Figure 1).

The underlying 120 meters of upper Pliocene to lower Miocene or upper Oligocene green-gray hemipelagic clays bear the first observed zeolites. Determining their pattern of distribution is difficult because zeolite concentrations never exceed 1 per cent, but zeolites tend 
TABLE 1

XRD Mineralogy of Sediments at Sites 382, 385, and 386

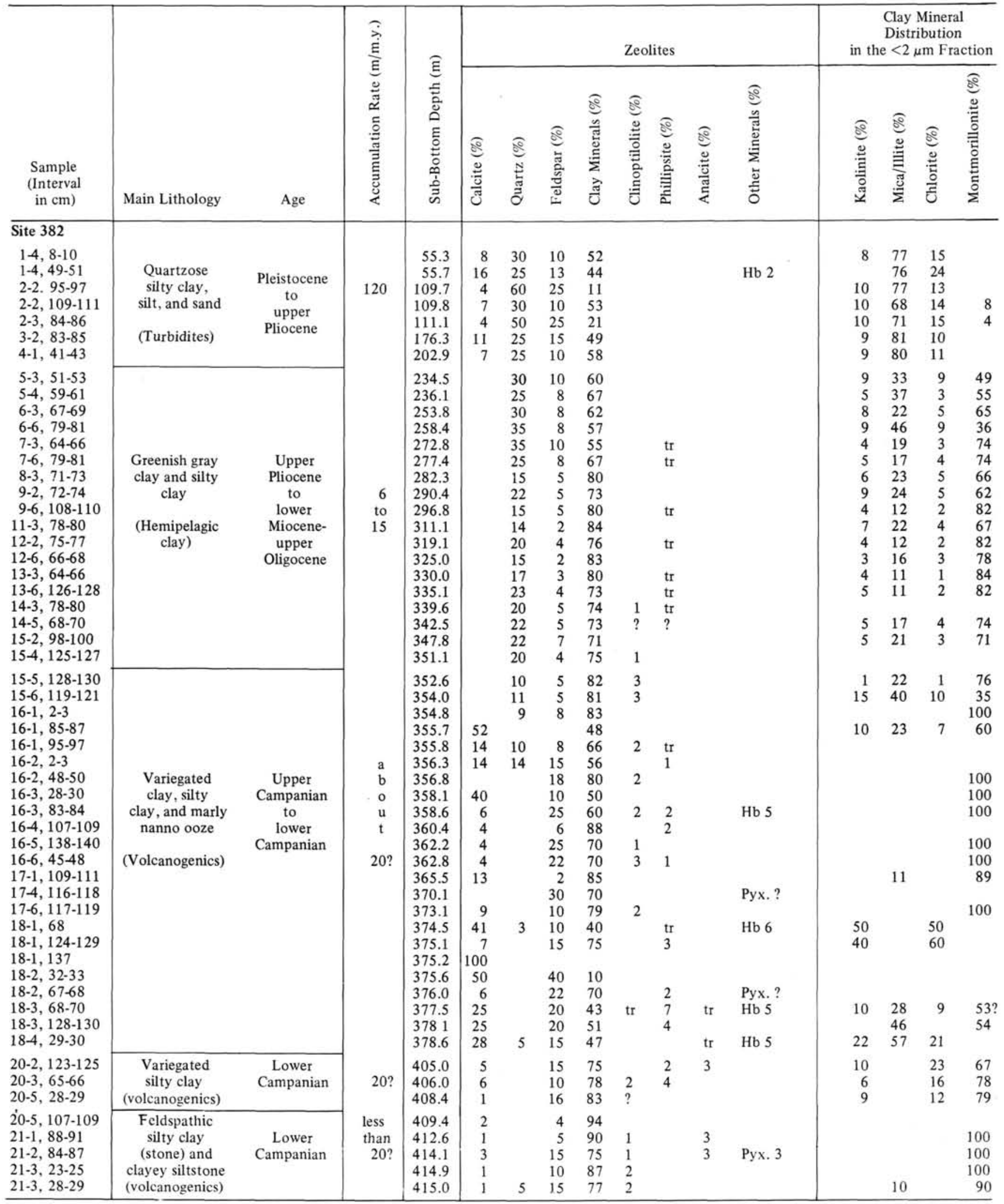


TABLE 1 - Continued

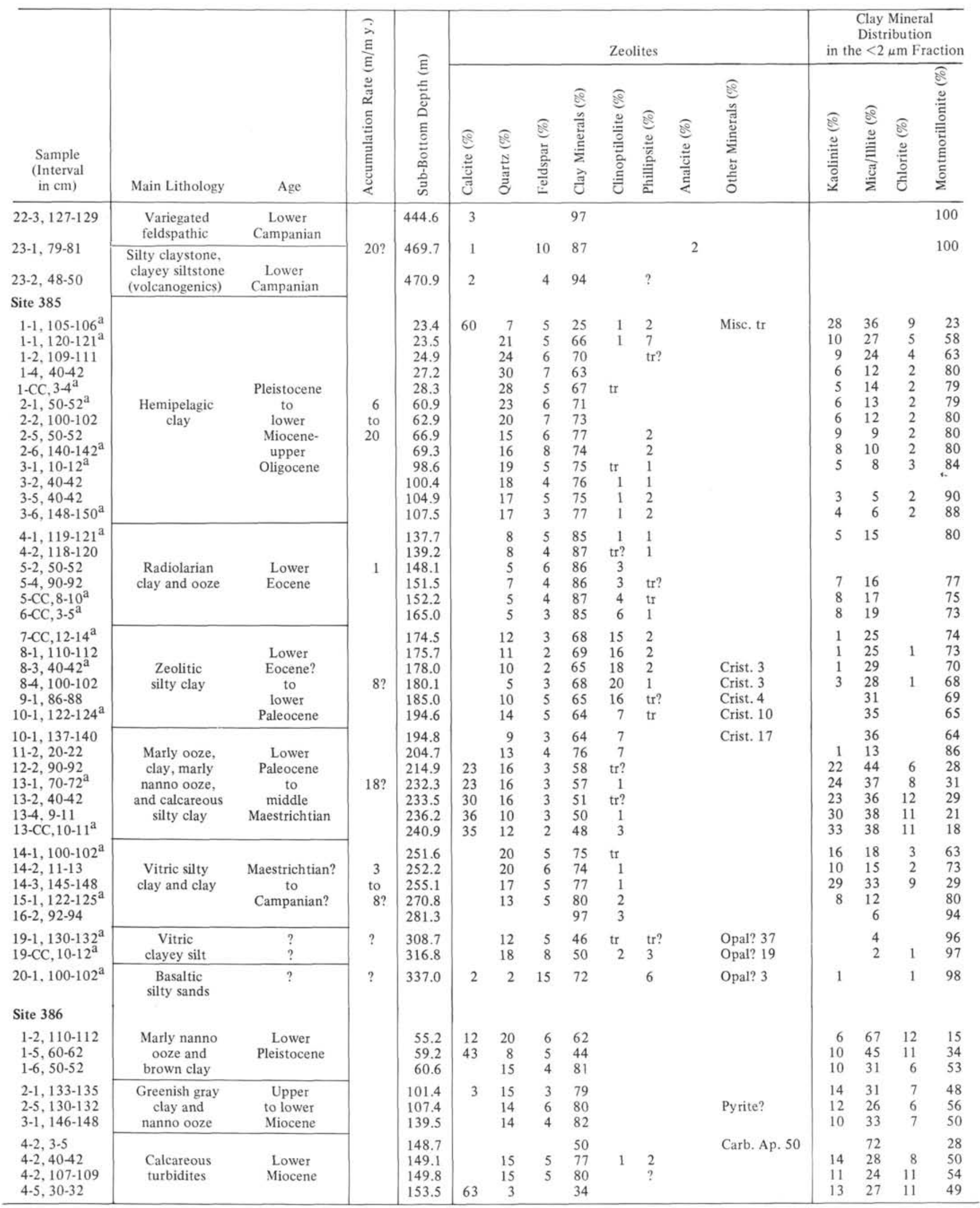


TABLE 1 - Continued

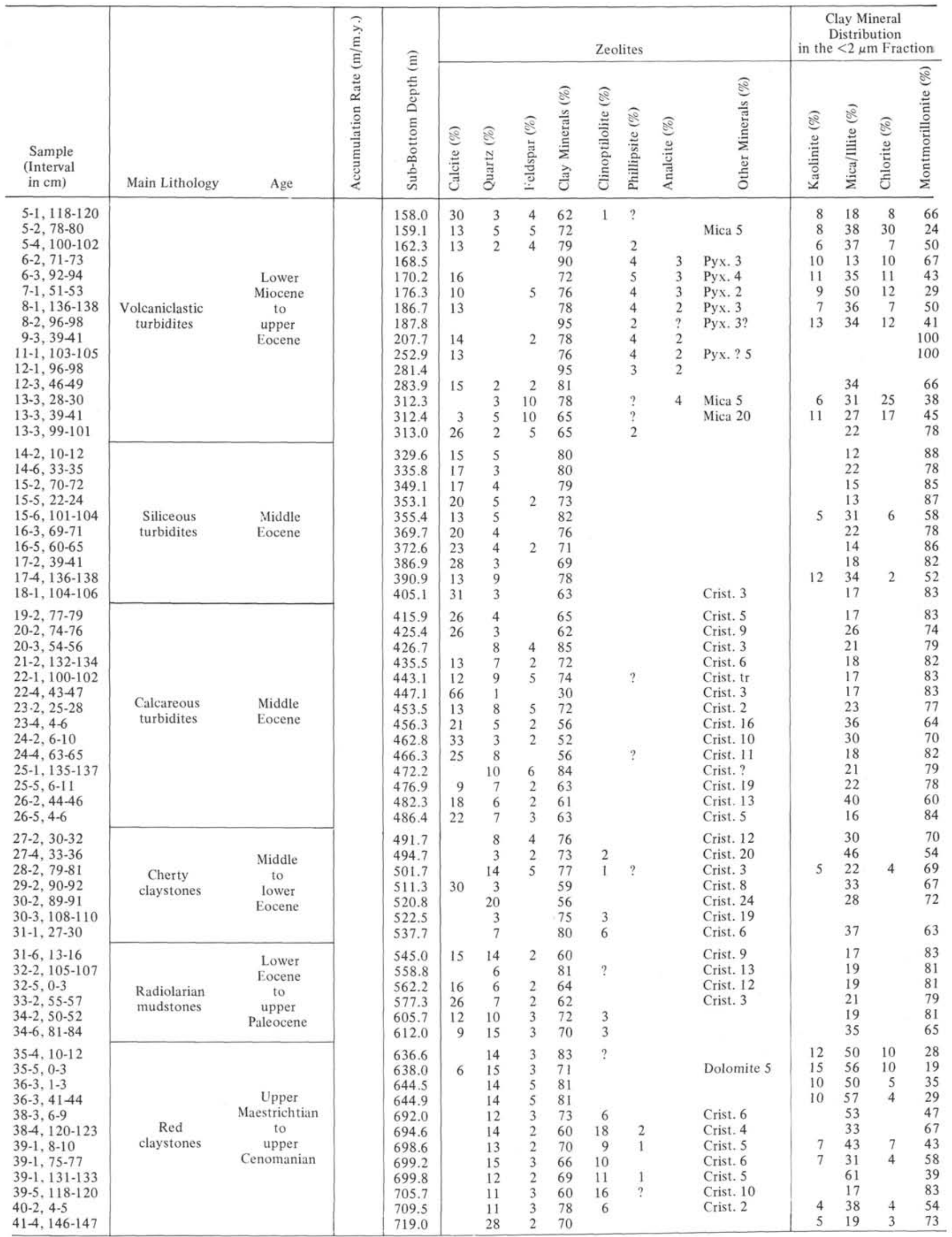


TABLE 1 - Continued

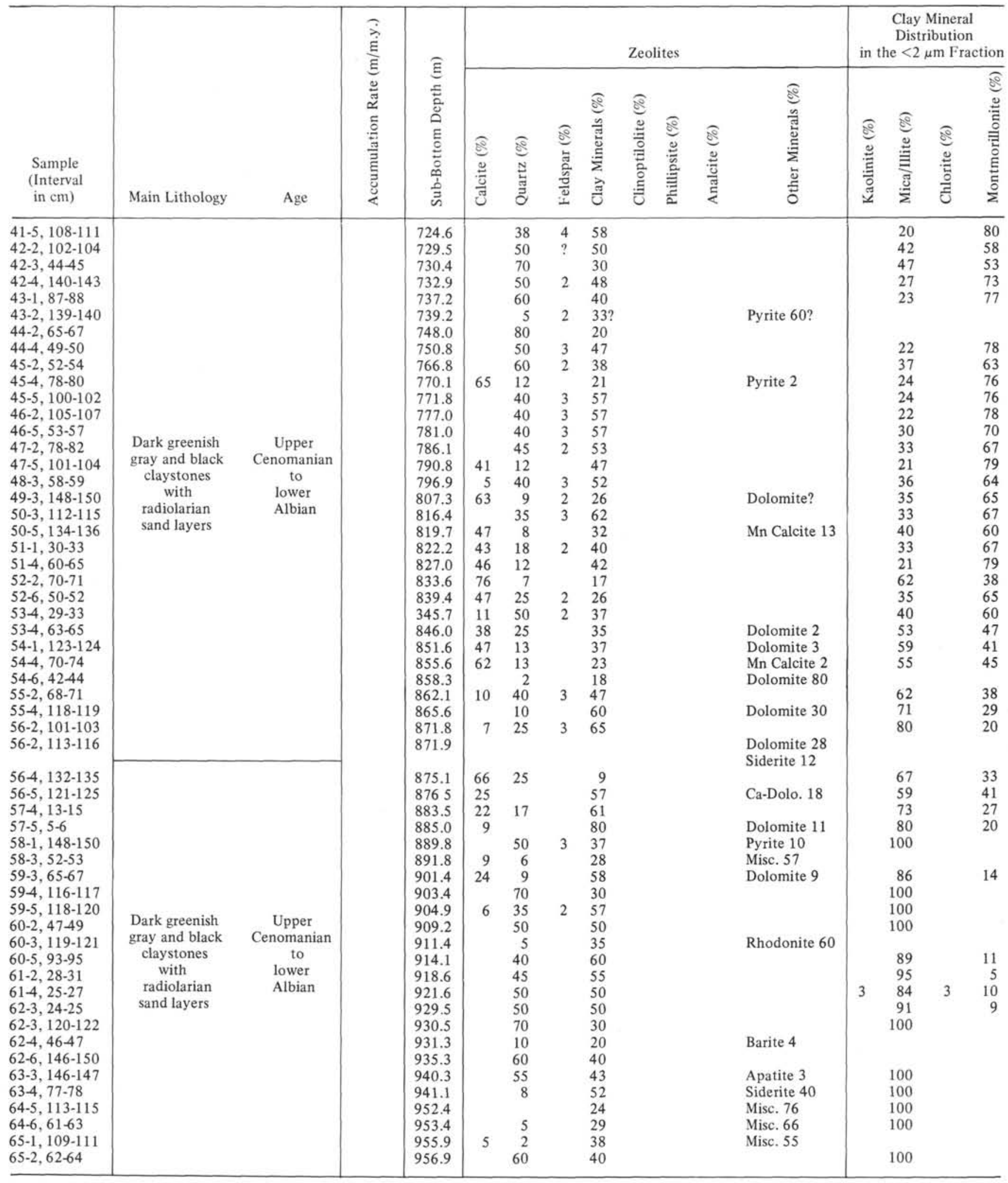

${ }^{\mathrm{a}}$ Samples analyzed at MIT. 


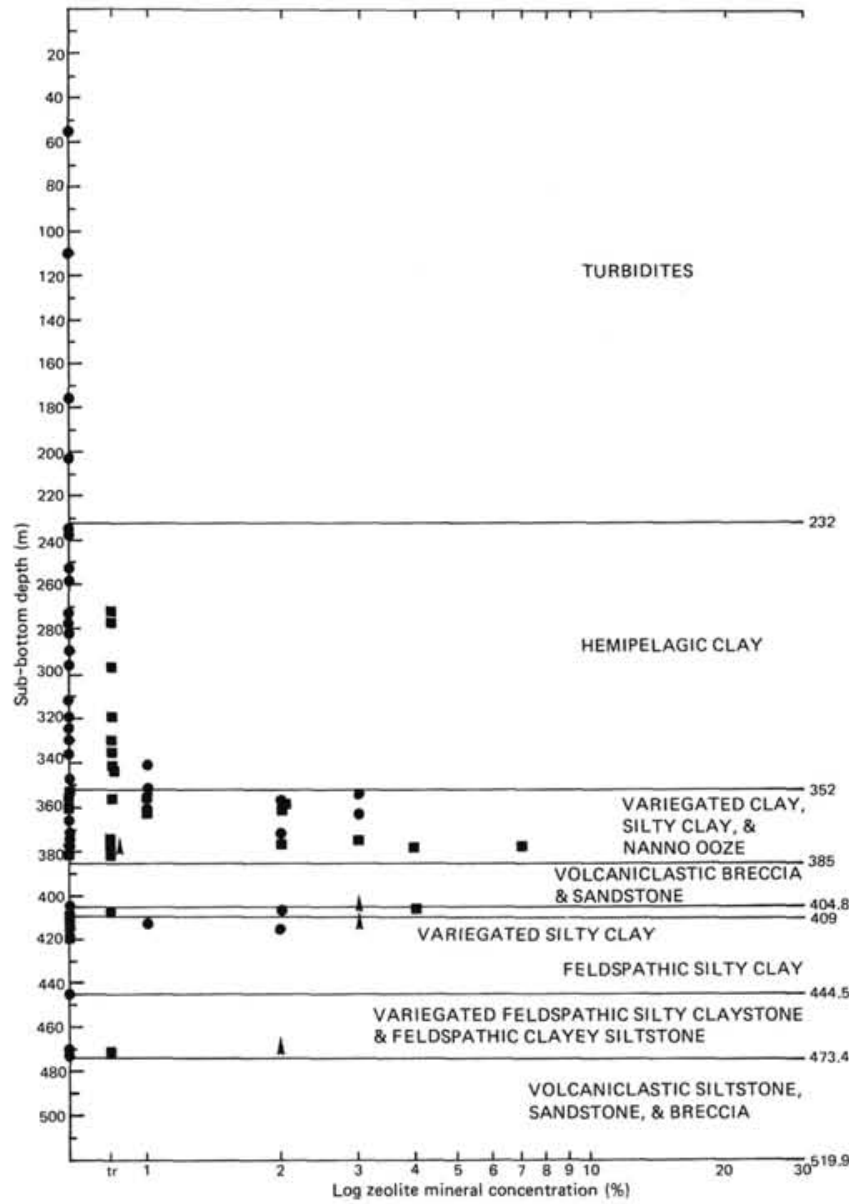

Figure 1. Downcore zeolite concentration at Site 382. Symbols are as follows: = phillipsite, $=$ clinoptilolite, and $\boldsymbol{\Delta}=$ analcite.

to be absent from beds with relatively less montmorillonite. Phillipsite appears in trace concentrations throughout the montmorillonite-rich lower section. Microscopically, the phillipsite separates consist of zoned 0.02 - to $0.08-\mathrm{mm}$, roughly equant monoclinic prisms $(\mathrm{n}=1.477-1.486)$, with rims having higher refractive indexes than cores (Figure 2). At the base of the unit, clinoptilolite supplants phillipsite and constitutes about 1 per cent of the sediment.

Thirty-three meters of upper to lower Campanian variegated clay, silty clay, and nannofossil ooze constitute the top of the volcaniclastic stratigraphic section at Site 382. Whereas the variegated nature of this unit reflects considerable lithologic and compositional variability, the sediment generally contains an increased carbonate component and abundant feldspar. Montmorillonite represents nearly the entire clay mineral fraction. Zeolite mineralogy and concentration display considerable variability (see Figure 1). Calcareous ooze interbeds are devoid of zeolites. Clinoptilolite, ranging to 3 per cent of the sediment, occurs as 1- to $3-\mu \mathrm{m}$ plate-like laths which are commonly irregular in outline and only rarely display a monoclinic, coffinshaped habit (Figure 3 ). Locally high clinoptilolite

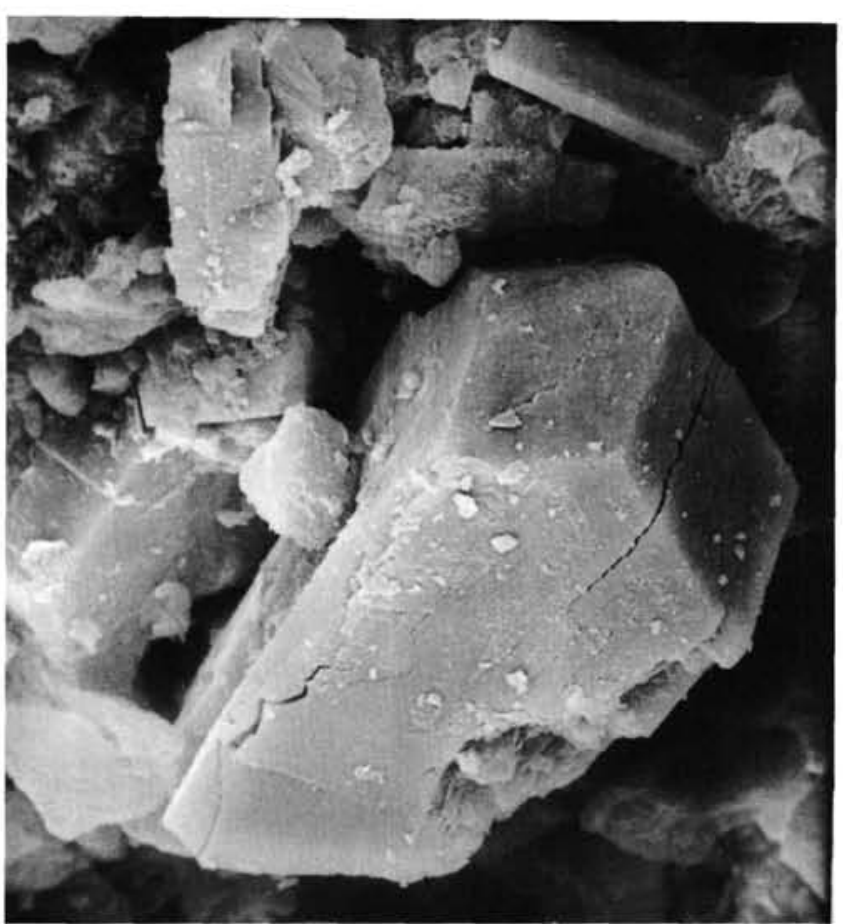

Figure 2. Roughly equant monoclinic phillipsite prisms in hemipelagic clay, Sample 382-15-3, 68-70 cm. SEM photograph.

abundances may reflect scattered occurrences of spherulitic aggregates similar to mineral balls described by von Rad and Rösch (1972). These spheres of radiating needles ( 3 to $5 \mathrm{~mm}$ in diameter) appear to

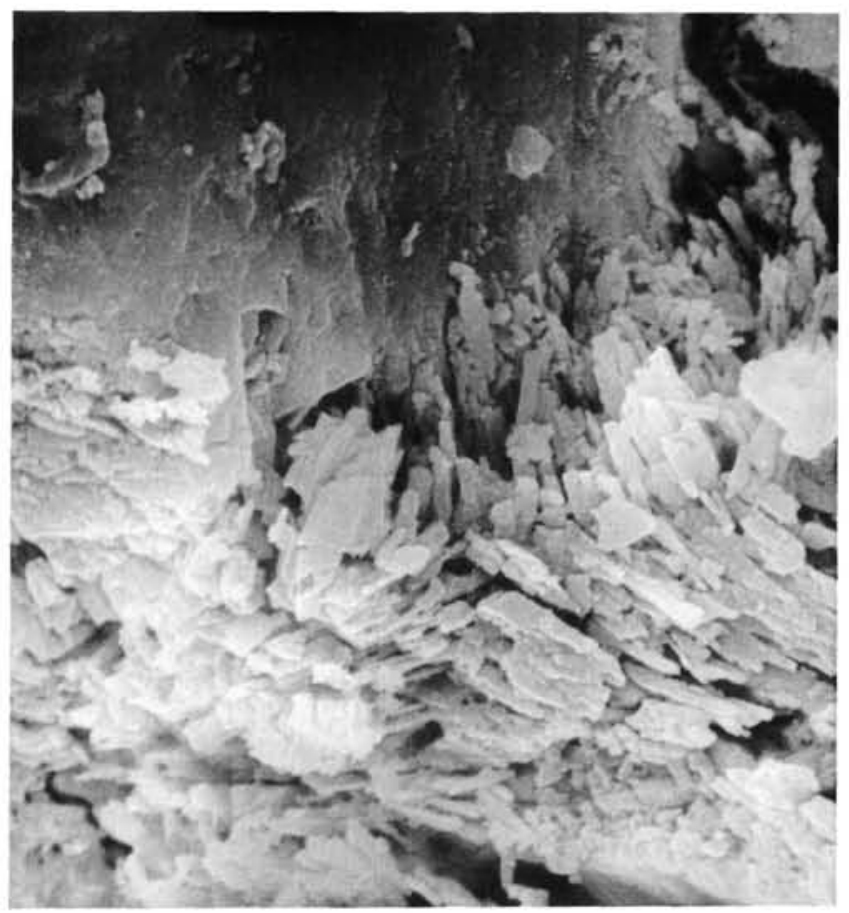

Figure 3. SEM micrograph of irregular clinoptilolite crystal in variegated clay, Sample $382-18-3,68-70 \mathrm{~cm}$. 
consist mainly of a core of highly corroded radiating lath-shaped high-temperature sanidine or orthoclase (Figure 4) encrusted with clinoptilolite blades. Montmorillonite and cristobalite can also be constituents of these mineral balls. Phillipsite, which ranges to 7 per cent of the sediment, is generally common throughout the unit but tends to increase in abundance at the base of this lithology. The highest concentrations of phillipsite occur in the silty vitric beds. The zeolite occurs as stout, stubby prisms, 1 to $7 \mu \mathrm{m}$ thick and 4 to $15 \mu \mathrm{m}$ in length (Figure 5). The pseudo-orthorhombic symmetry of the phillipsite is generally evident, and "cracking", along cleavage surfaces parallel to the axis of elongation, as noted by Mumpton and Ormsby (1976), is common. Trace concentrations of analcite were also suggested by XRD.

The underlying volcaniclastic sandstone and breccia consist of poorly graded and sorted, subangular to subrounded crystal- and basaltic-lapilli in varying states of alteration, cemented by calcite and phillipsite. Individual basaltic clasts yield both clinoptilolite and phillipsite. As in the overlying variegated clays, the clinoptilolite is associated with radiating spherulites centering around sanidine.

The variegated silty clay recovered beneath the breccia displays zeolite concentrations similar to those of the overlying variegated clay and silty clay, with clinoptilolite ranging up to 2 per cent, phillipsite to 4 per cent, and analcite to 3 per cent of the sediment. The bulk composition of this unit, however, is considerably different. Calcite concentrations average only 4 per cent, much lower than in the variegated clay.

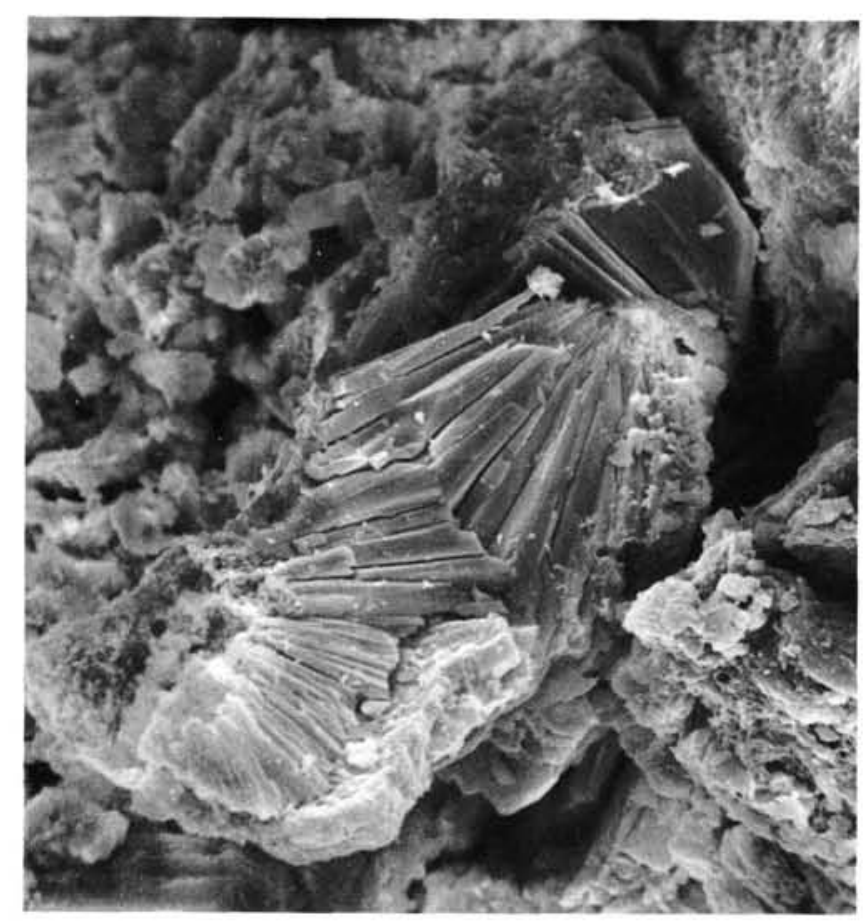

Figure 4. SEM micrograph of radiating laths of hightemperature sanidine in variegated clay, Sample 382 $16-6,45-48 \mathrm{~cm}$.

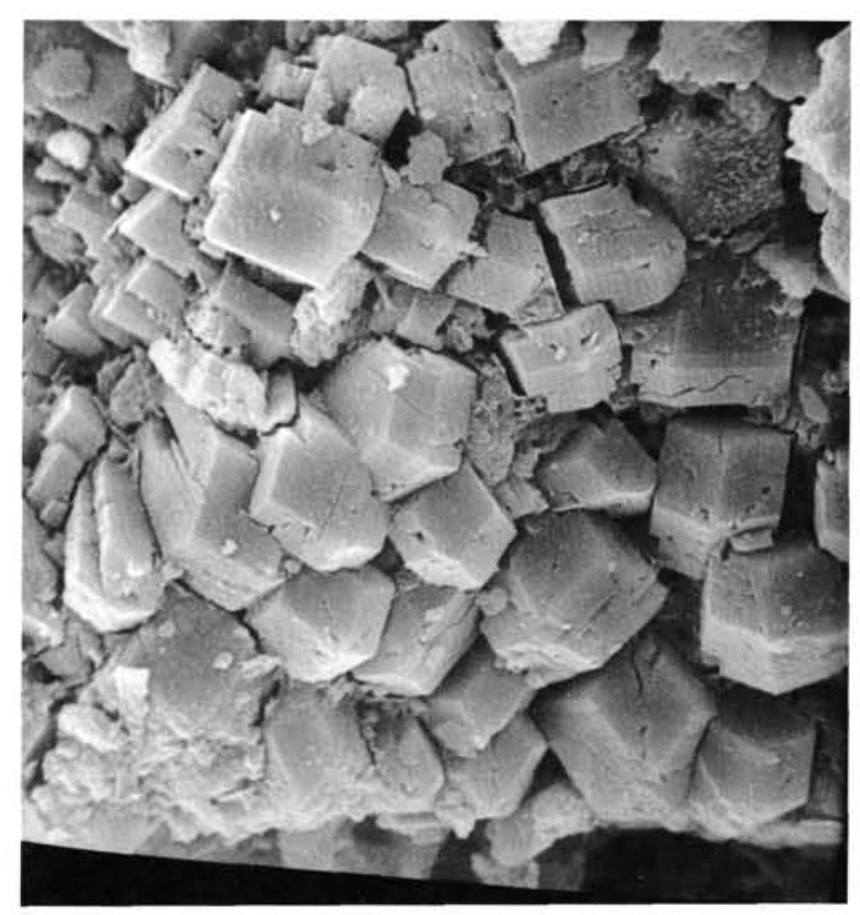

Figure 5. SEM micrograph of stout phillipsite prisms in variegated clay, Sample $382-18-3,68-70 \mathrm{~cm}$.

Quartz is absent, and whereas montmorillonite is still the dominant clay mineral, chlorite is also an important constituent. Zeolites generally occur in their most simple habits as single crystals and are only rarely associated with spherulitic aggregates.

Although sampled only in its upper part, the feldspathic silty clay unit at Site 382 appears to lack phillipsite as a sedimentary component. Clinoptilolite is universally present, averaging 2 per cent, and analcite is locally dominant, in places making up 3 per cent of the sediment. Feldspar is locally abundant, and montmorillonite constitutes nearly all of the clay mineral fraction of the sediment.

Lower Campanian variegated feldspathic silty claystone which overlies acoustic basement at this site lacks zeolites, although a trace amount of phillipsite was recognized in XRD patterns of sediment at the base of the unit. A single sample also suggests up to 2 per cent analcite.

Acoustic basement at Site 382 consists of volcaniclastic breccia virtually identical to the breccia unit penetrated above. Phillipsite is the dominant zeolite serving to cement the lapilli, whereas clinoptilolite is occasionally found within basaltic clasts in association with potassium feldspar.

\section{Site 385-Vogel Seamount}

Site 385 was drilled in the volcaniclastic apron on the north flank of Vogel Seamount. The thick turbidite sequence encountered at Site 382 is absent here. The stratigraphically highest lithologic unit is an olive-gray hemipelagic clay similar to that drilled on Nashville Seamount (Figure 6). Holocene nanno-foram ooze, 0.15 meter thick, probably punch-cored while "feel- 


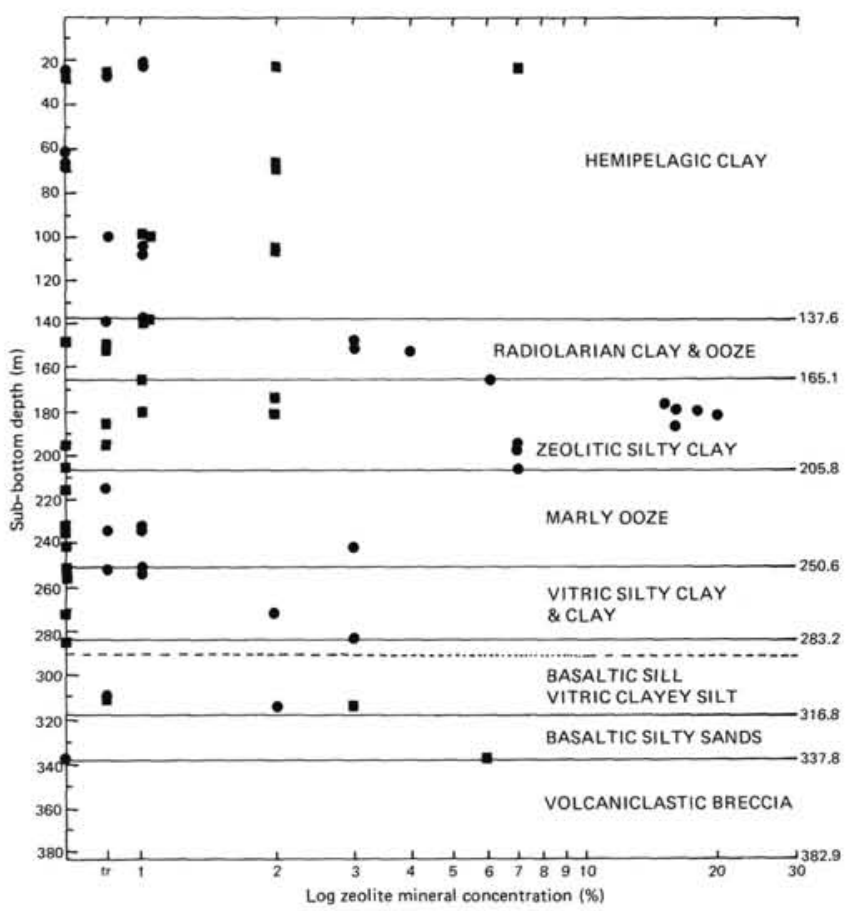

Figure 6. Downcore zeolite concentration at Site 385. Symbols are the same as used in Figure 1.

ing" for bottom without circulation, overlies the clay. The ooze contains trace amounts of both phillipsite and clinoptilolite. XRD shows that the uppermost recovered sediment from the carbonate-poor hemipelagic clay contains 8 per cent zeolites, of which 1 per cent is clinoptilolite and the remainder phillipsite. The zoned phillipsite crystals are readily identifiable by their pseudo-orthorhombic habit. Phillipsite crystals also display extensive pitting consistent with the reports of solution and etching of some phillipsites from Sylvania Guyot (Rex, 1967). As at Site 382, clinoptilolite is more abundant near the base of the unit.

Disconformably underlying the hemipelagic clays are 27.5 meters of middle to lower Eocene radiolarian clay and ooze. The zeolites in this siliceous unit are dominated by clinoptilolite, which ranges to 6 per cent of the sediment. The clinoptilolite from this radiolarian-rich unit has a habit much narrower than that previously described and resembles laths rather than plates. Single prisms of phillipsite occur throughout the unit in trace concentrations, enriched to 1 per cent near the upper and lower boundaries.

The highest concentrations of zeolites recovered during Leg 43 were observed in the lower Eocene to lower Paleocene zeolitic silty clay ( 165.1 to $205.8 \mathrm{~m}$ ) at Site 385 . Whereas phillipsite morphology and concentrations resemble those encountered in the two overlying units, clinoptilolite reaches 20 per cent at the center of the unit, and is relatively enriched in the coarsest layers. This clinoptilolite appears as spherulitic aggregates identical to those described from Site 382 . Cores of high sanidine are more common than cores of orthoclase. Zeolite-rich layers are rich in disordered cristobalite and opal (up to 17 per cent) and show relatively higher illite/montmorillonite ratios than the surrounding sediment.

The underlying Paleocene to middle Maestrichtian marly ooze and clay is devoid of phillipsite. Ragged plates of clinoptilolite are similar to those encrusting potassium feldspar in the overlying silty clay, however, are common (up to 3 per cent), and increase in abundance with depth.

Despite the abundance of altered ash in the vitric silty clay and clay, phillipsite is also absent from this unit, as in the overlying marly ooze. Clinoptilolite is present throughout (averaging between 1 and 2 percent) as irregular blades and plates. The sediment is rich in silica; the clay fraction is dominated by montmorillonite.

A similar clinoptilolite-bearing vitric clayey silt is present below a basaltic intrusion. Stout subhedral to euhedral prisms of phillipsite, however, increase in abundance down-section (to 3 per cent).

A thin horizon of basaltic silty sands is characterized by sand-sized clasts of extremely altered basalt and abundant montmorillonite. Phillipsite constitutes up to 6 per cent of the unit, whereas clinoptilolite is apparently absent. The zeolite occurs both as stubby prisms (Figure 7) and as radial vesicle fillings in the basalt.

As at Site 382, drilling on Vogel Seamount terminated in Cretaceous volcaniclastic breccia. Altered basalt lapilli are cemented by varying proportions of calcite and radial phillipsite. Basaltic clasts yield both clinoptilolite and phillipsite. Zeolitic vesicle fillings and

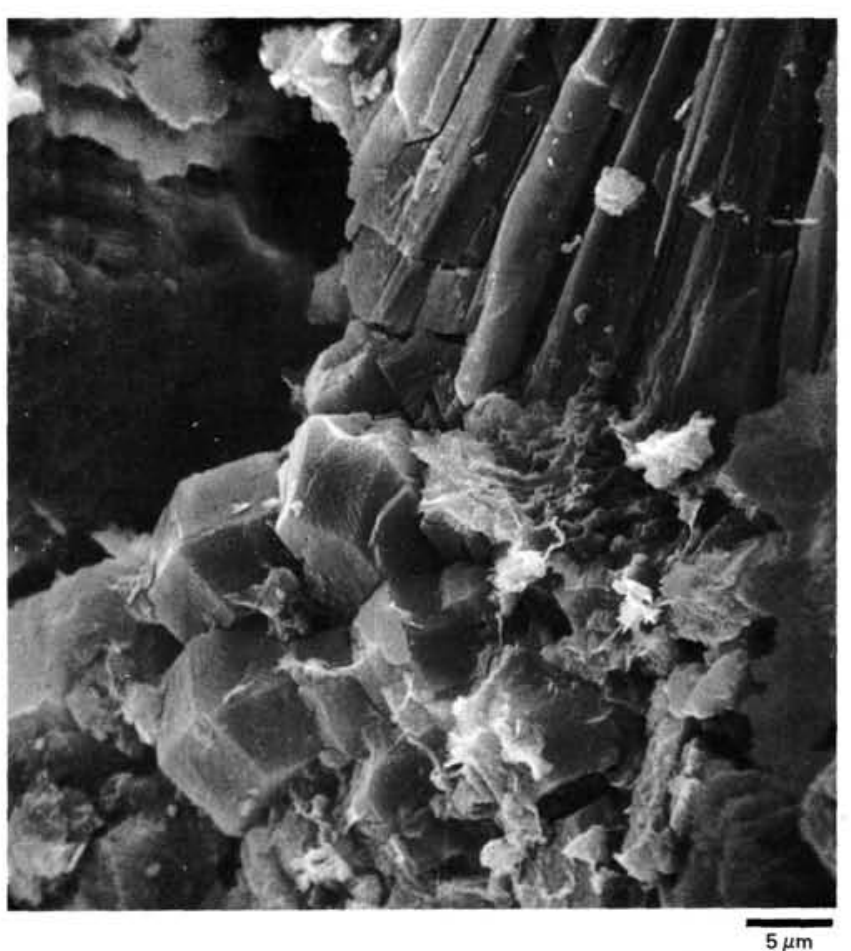

Figure 7. SEM micrograph of stubby phillipsite prisms in basaltic silty sands, Sample 385-19, CC, 10-12 cm. 
altered groundmass are entirely composed of phillipsite. Clinoptilolite surrounds "pseudo-amygdules" of high-temperature sanidine. Rare zones of selvage on some of the clasts also have phillipsite associations. Isolated angular cavities interpreted as "fossil" shard locations occasionally appear in otherwise completely zeolitized regions of clast margins.

\section{Site 386-Central Bermuda Rise}

Hole 386 was drilled 974 meters into the central Bermuda Rise. The stratigraphically highest sediment recovered is lower Pleistocene marly nannofossil ooze and brown clay. Carbonate and clay minerals vary widely within the unit, but constitute less than 70 per cent of the sediment. Mica/illite averages about half of the clay mineral composition and montmorillonite about a third. Zeolites are absent (Figure 8).

Underlying this ooze is a similar unit of upper to lower Miocene greenish gray clay and nanno ooze. Except for the thin calcareous base of the unit, clay constitutes 80 per cent of the sediment. Montmorillonite dominates the clay mineral fraction, but mica/illite remains an important constitutent. Except for isolated stringers rich in phillipsite, zeolites are also absent.

Lower Miocene calcareous turbidites constitute a thin $(9.5-\mathrm{m})$ unit in which grading is responsible for large compositional variability. The calcareous turbidites are capped by a thin layer with 50 per cent detrital apatite, the remainder being clay dominated by mica/ illite. The poorly sorted middle layers of the unit consist of 80 per cent clay and lesser quartz and feldspar. Montmorillonite is the most abundant component of the clay mineral fraction. Zeolites were observed only in this portion of the unit. Phillipsite and clinoptilolite occur as single laths with the former about twice as abundant, ranging up to 2 per cent of the sediment. A basal clayey sand, rich in skeletal carbonate and devoid of zeolites, completes the unit.

More than 150 meters of lower Miocene to upper Eocene volcaniclastic turbidites underlie the calcareous turbidites. The bulk of the sequence consists of graded clays containing 10 to 30 per cent carbonate. The clay mineral fraction is largely montmorillonite, consistent with a volcanic source. Basal sandy layers consist essentially of heavy minerals dominated by clinopyroxene and magnetite with lesser mica, apatite, hornblende, epidote, chrome spinel, and garnet (see Galehouse, this volume). Although zeolites are common throughout, clinoptilolite is absent. Phillipsite and analcite are common throughout, averaging 2 to 3 per cent each. The phillipsite was observed both as free pseudo-orthorhombic crystals (Figure 9) 5 to $40 \mu \mathrm{m}$ in length and 1 to $10 \mu \mathrm{m}$ thick, and as zoned, complexly intergrown laths in altered basaltic glass (Figures 10 and 11). Analcite occurs as subhedral to anhedral cubo-octahedral crystals commonly 10 to $40 \mu \mathrm{m}$ in diameter. Such crystals are commonly corroded and cleaved into angular masses (Figure 12).

Poorly sorted but well graded middle Eocene siliceous turbidites underlie the volcaniclastic sequence. Carbonate concentrations range from 15 to 30 per cent

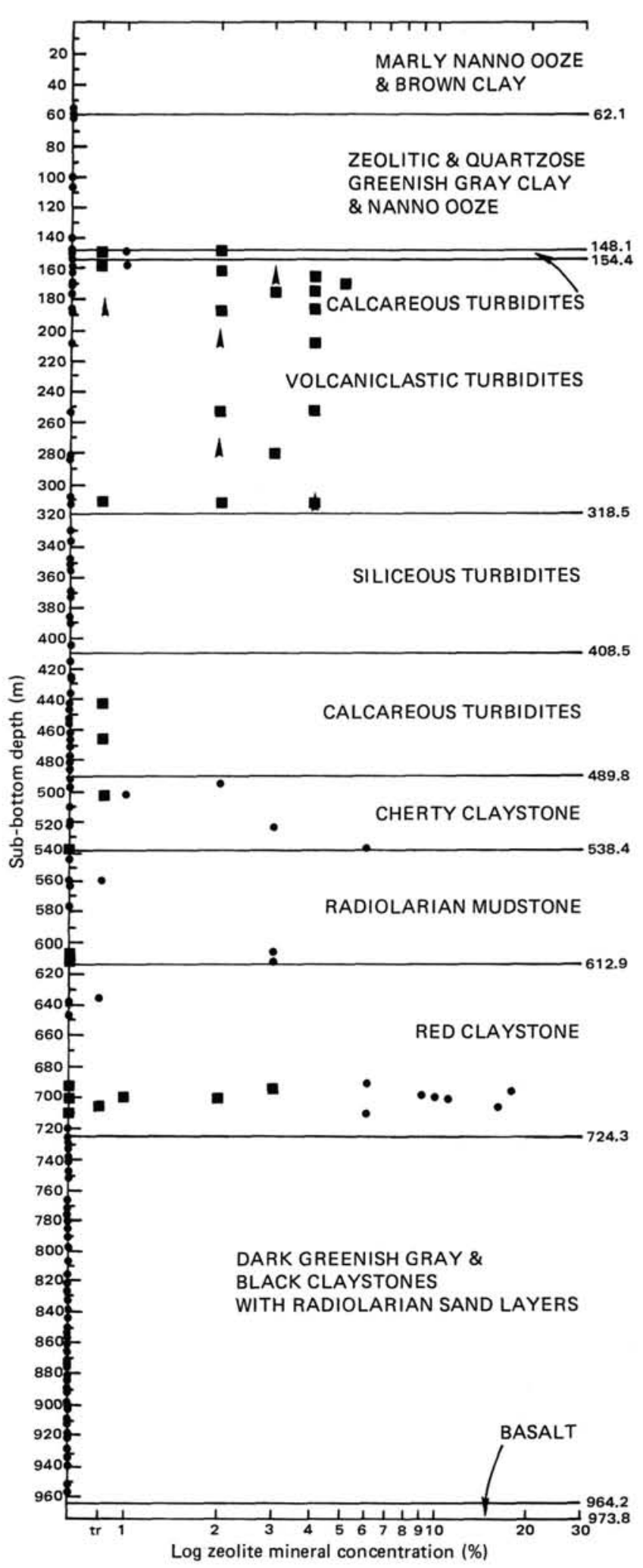

Figure 8. Downcore zeolite concentration at Site 386. Symbols are the same as used in Figure 1.

within the unit. Although montmorillonite greatly dominates the clay mineral fraction of the sediment, no zeolites are present. 


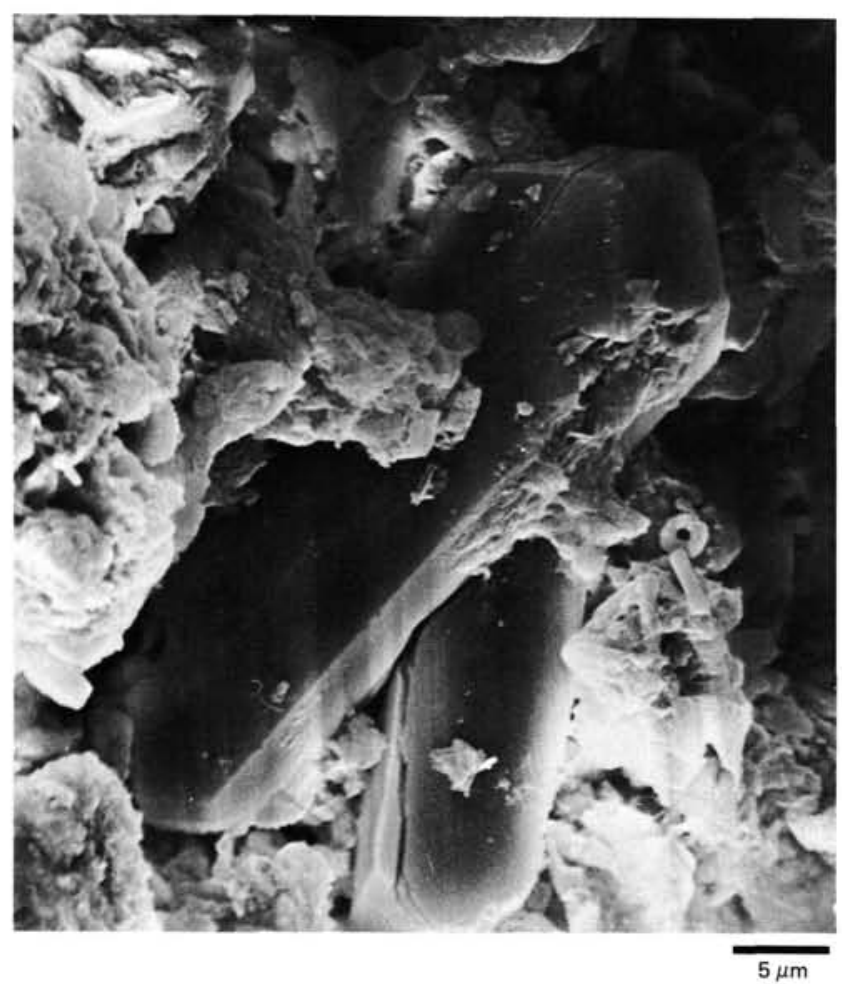

Figure 9. SEM micrograph of pseudo-orthorhombic phillipsite crystals in volcaniclastic turbidites, Sample 386$5-2,78-80 \mathrm{~cm}$.

The next turbidite sequence drilled consists of about 80 meters of middle Eocene calcareous turbidites of a texture and color nearly identical to the earlier encountered calcareous turbidite unit. Carbonate content ranges from 0 to 66 per cent and averages about 20 per cent. The clay fraction ranges from 30 to 85 per cent and is dominated by montmorillonite. Disordered cristobalite and opal reach concentrations up to 20 per cent. Zeolites are generally absent; only isolated trace occurrences of phillipsite laths were noted.

About 50 meters of greenish gray middle to lower Eocene cherty claystones underlie the turbidites. Light stringers of carbonate-rich claystone occasionally interrupt the unit. In smear slides, recrystallized radiolarians are readily recognized as the source for much of the unit's silica. Disordered cristobalite and opal are common throughout, ranging from 3 to 24 per cent. Up to 6 per cent clinoptilolite occurs in the cherty claystones, whereas other zeolites are generally absent. Carbonaterich layers are devoid of zeolites.

Underlying the cherty claystones are about 75 meters of lower Eocene to upper Paleocene radiolarian mudstones. Compositionally, these sediments are very similar to the overlying claystones except for an increased calcareous component in the mudstones. Clinoptilolite, the only zeolite present, does not appear above trace concentrations above the base of the unit. Significantly, this lowest sediment also lacks cristobalite as a major component.
About 100 meters of upper Maestrichtian to upper Cenomanian red claystones underlie the radiolarian mudstones and can be divided into an upper nonzeolitic and a lower zeolitic portion. The upper portion averages about 14 per cent quartz, 4 per cent feldspar, and 79 per cent clay minerals dominated by mica/ illite. Dolomite and calcite occur locally. The basal zeolitic portion of the unit contains similar amounts of quartz and feldspar but averages only about 68 per cent clay minerals, about one-third mica/illite, and more than half montmorillonite. Cristobalite occurs instead of dolomite, and zeolites, ranging up to 20 per cent and averaging 10 per cent, complete the sediment's important constituents. Euhedral truncated monoclinic plates of clinoptilolite (Figure 13), 6 to 13 $\mu \mathrm{m}$ long and 1 to $5 \mu \mathrm{m}$ thick, constitute nearly all the observed zeolite. A single harmotome twin partially encrusted with phillipsite (Figure 14) was also observed in the middle part of the unit.

The remaining sedimentary section at Site 386 consists of about 240 meters of upper Cenomanian to lower Albian, dark greenish-gray to black claystones interbedded with radiolarian sands. Calcite, quartz, and clay minerals dominate the bulk composition of the unit, with several other minerals locally abundant.

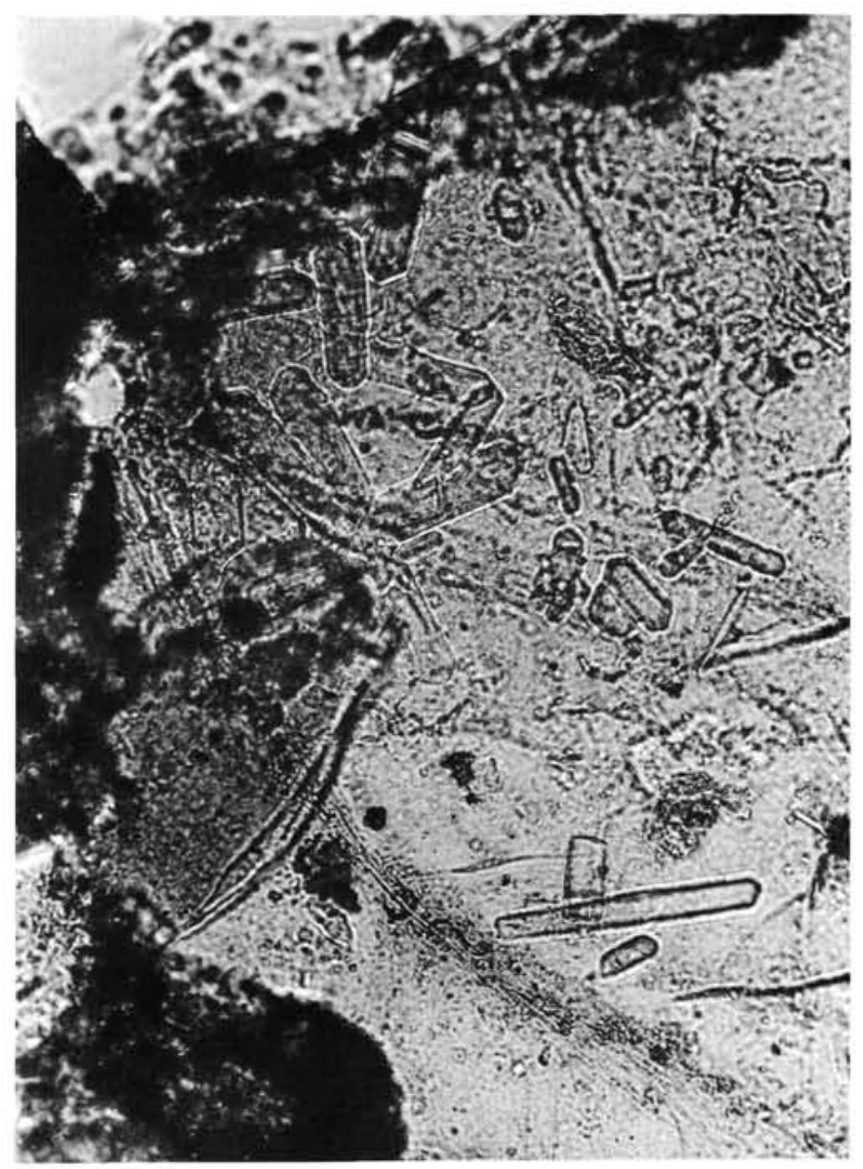

Figure 10. Petrographic micrograph of phillipsite laths in altered basaltic glass, Sample 386-5-2, $78 \mathrm{~cm}$. 


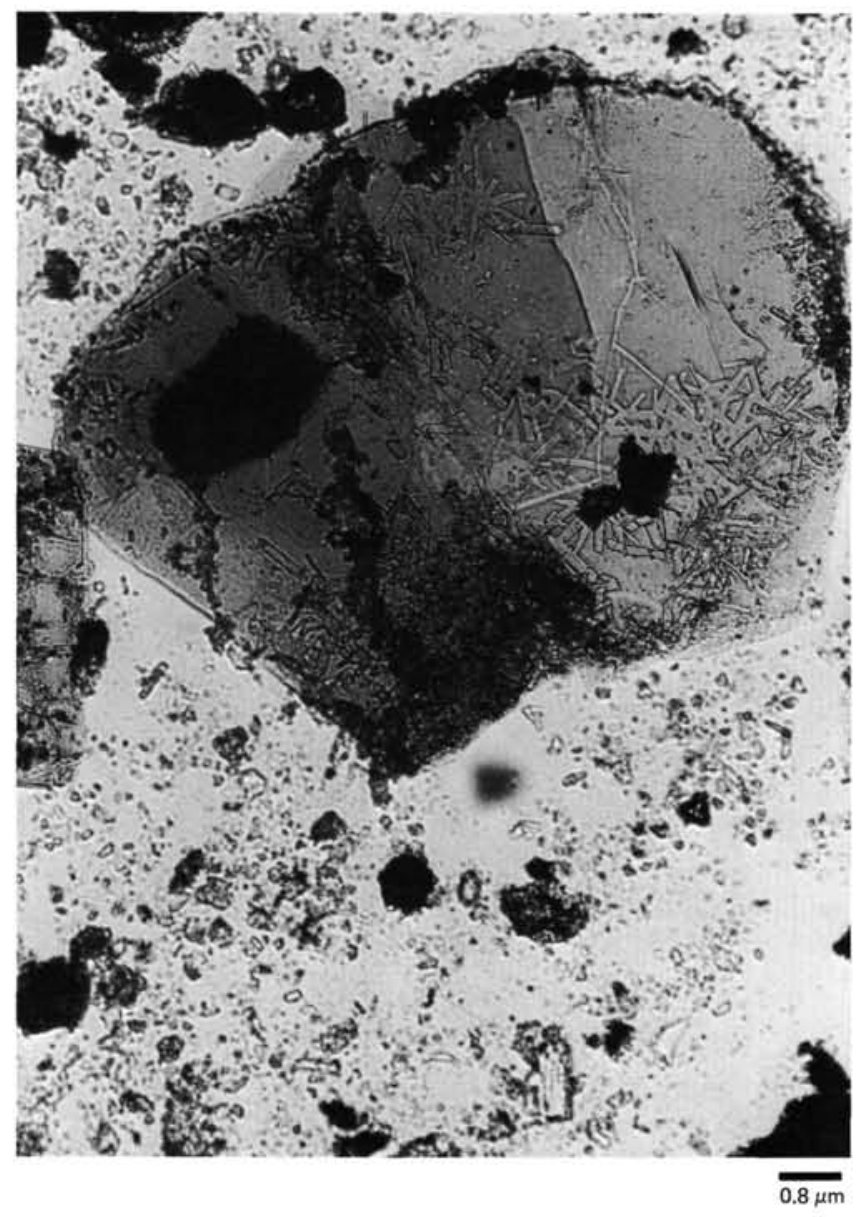

Figure 11. Petrographic micrograph of phillipsite laths in altered basaltic glass, Sample 386-5-2, $78 \mathrm{~cm}$.

Montmorillonite is the dominant clay mineral in the upper half of the unit, constituting about two-thirds of the clay fraction, with mica/illite constituting about one-third. In the lower half, however, mica/illite strongly dominates, averaging nearly 85 per cent of the clay fraction. Whereas XRD analyses of the bulk sediment failed to reveal any zeolites, rare monoclinic crystal clusters of clinoptilolite (Figure 15) and cubelike rhombohedra of chabazite (Figure 16) were noted in smears of the radiolarian sands and confirmed by XRD of mineral separates.

Nearly 2 meters of basalt basement extensively veined with calcite were recovered from the bottom of the hole at Site 386. The abyssal tholeiite is extensively altered (see Houghton, this volume) but bears only rare phillipsite associated with montmorillonite, which replaces former glass.

\section{DISCUSSION}

On the basis of correlations with associated parameters, various processes of origin can be suggested to explain the observed distributions of the zeolites. These modes of origin should not be considered as unique, however, but in our opinion only as the most probable ones.
The distributions of clinoptilolite and phillipsite in Atlantic Ocean sediments are related to bathymetry. Clinoptilolite apparently dominates the zeolite fraction of sea-floor sediments, whereas phillipsite occurs only in the sediments on the higher seamounts and islands. Sites 382 and 385 on the New England seamounts might thus be expected to have similar zeolite character and will be discussed jointly here.

The surface sediment on the eastern flank of Nashville Seamount at Site 382 is barren of zeolites and consists of turbidites probably derived from the Laurentian Channel. Such an alkali plutonic source region as the Canadian Shield does not usually generate much zeolite; further, zeolite minerals are rarely detrital (Hay, 1966; Stonecipher, 1976). Zeolites most commonly form by the alteration of volcanic debris (Coombs et al., 1959), and the near absence of montmorillonite in the clay mineral fraction suggests no such volcanic contribution to the turbidites.

At Site 385 on Vogel Seamount, instead of turbidites, the surface sediment is pelagic nanno-foram ooze. In line with the above observations, phillipsite appears to dominate clinoptilolite, although both occur only in small amounts. As only a single sample of this ooze was studied, variations in indicators of genesis with zeolite concentration are impossible to evaluate. It appears likely that the phillipsite and clinoptilolite could have formed either authigenically or by alteration of detrital components such as montmorillonite and potassium feldspar, respectively.

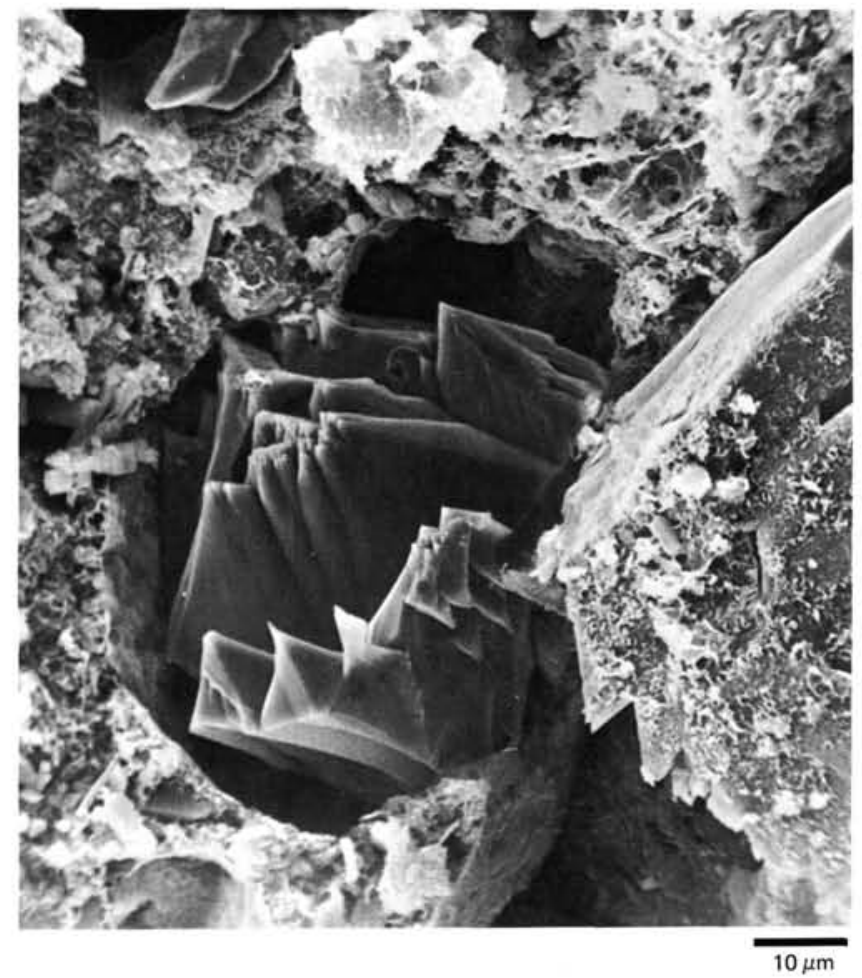

Figure 12. SEM micrograph of analcite crystals in volcaniclastic turbidites, Sample 386-13-3, $28-30 \mathrm{~cm}$. 


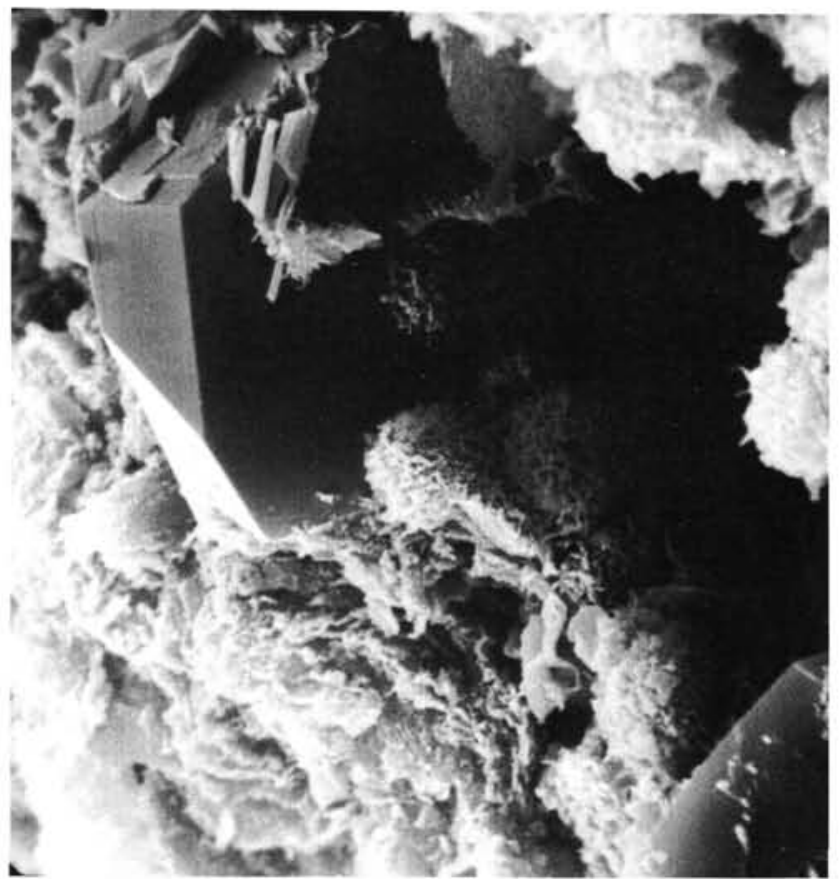

Figure 13. SEM micrograph of truncated monoclinic clinoptilolite crystal in red claystones, Sample 386-38-4, 120 $\mathrm{cm}$.

Underlying these sediments on both seamounts is a thick section of hemipelagic clay with phillipsite as the dominant zeolite component. As phillipsite is absent in beds relatively low in montmorillonite ( 70 per cent of the clay mineral fraction) and most abundant in layers with a higher montmorillonite content, montmorillonite may be directly related to phillipsite genesis in these clays. Such a relationship could be due to direct formation of the zeolite from this clay, authigenic formation catalyzed by the presence of the clay, or formation as a result of the presence of an agent associated with montmorillonite or its formation.

In Atlantic sediments, montmorillonite may be formed by at least three different mechanisms: (1) as detrital weathering residues (Biscaye, 1964), (2) as secondary products of degraded detrital mica or chlorite (Yeroshchev-Shak, 1964), or (3) as in situ products of the submarine weathering of volcanic material (Goldberg, 1964). Griffin et al. (1968) have concluded method (2) is not important in the North Atlantic. Because other indicators of a volcanic contribution are absent from these hemipelagic units, method (3) is also considered to be an unlikely contributor to the montmorillonite fraction. If essentially all the montmorillonite in the hemipelagic units is detrital, an associated agent causing zeolite formation is improbable. It seems reasonable, then, that the phillipsite in this hemipelagic unit formed by reorganization of disordered montmorillonite as suggested by Hay (1966). An authigenic origin cannot be ruled out, however.

Clinoptilolite is more abundant near the base of the hemipelagic unit at both sites drilled. No parameters within the clays suggest an internal explanation for this increase. As the underlying units at each site are relatively enriched in clinoptilolite, contamination from these sources is likely.

On Vogel Seamount, the hemipelagic clays are unconformably underlain by radiolarian clay and ooze. In this unit, phillipsite is only present in trace amounts, save at the unit's upper and lower margins, where the unit is in close association with relatively phillipsiteenriched beds. The occurrence and dominance of clinoptilolite in this siliceous unit appear to be related to altered radiolarian tests. As suggested by Goodell (1965), the silica released by dissolution of these organisms may explain production of clinoptilolite in the sediment rather than a less silica-rich zeolite.

The greatest variety of zeolite minerals occurs in the volcaniclastic sections of these sediments. At Site 382 on Nashville Seamount, the variegated clay and the variegated silty clay units have similar zeolite character. Phillipsite is dominant throughout these units and most concentrated in the silty vitric beds. Zeolites are most commonly the alteration products of volcanic glass (Coombs et al., 1959; Hay, 1966). As the glass is basaltic, this mode of genesis satisfactorily explains the phillipsite occurrence in these units but is inadequate to explain the clinoptilolite distribution. Thus, the absence

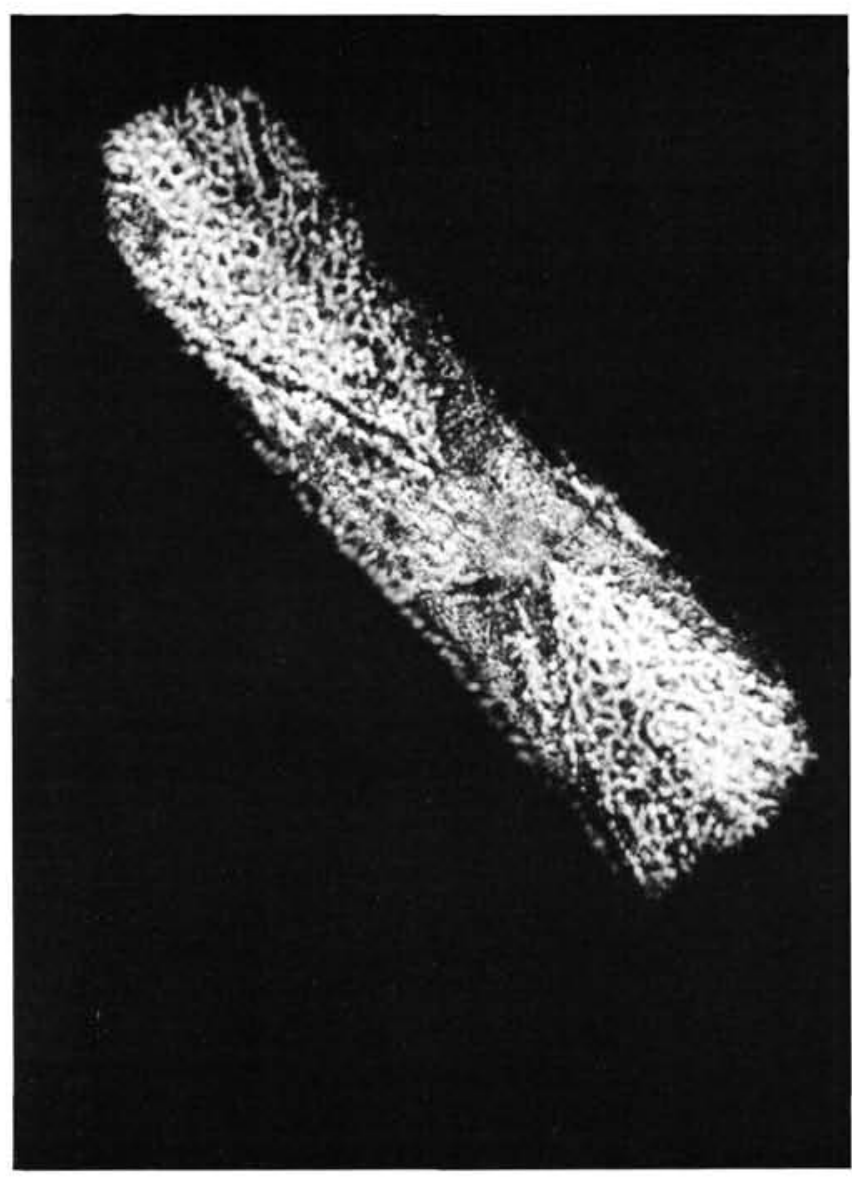

Figure 14. Petrographic micrograph of a twinned harmotome crystal encrusted with phillipsite in red claystones, Sample 386-39-1, $75 \mathrm{~cm}$. 


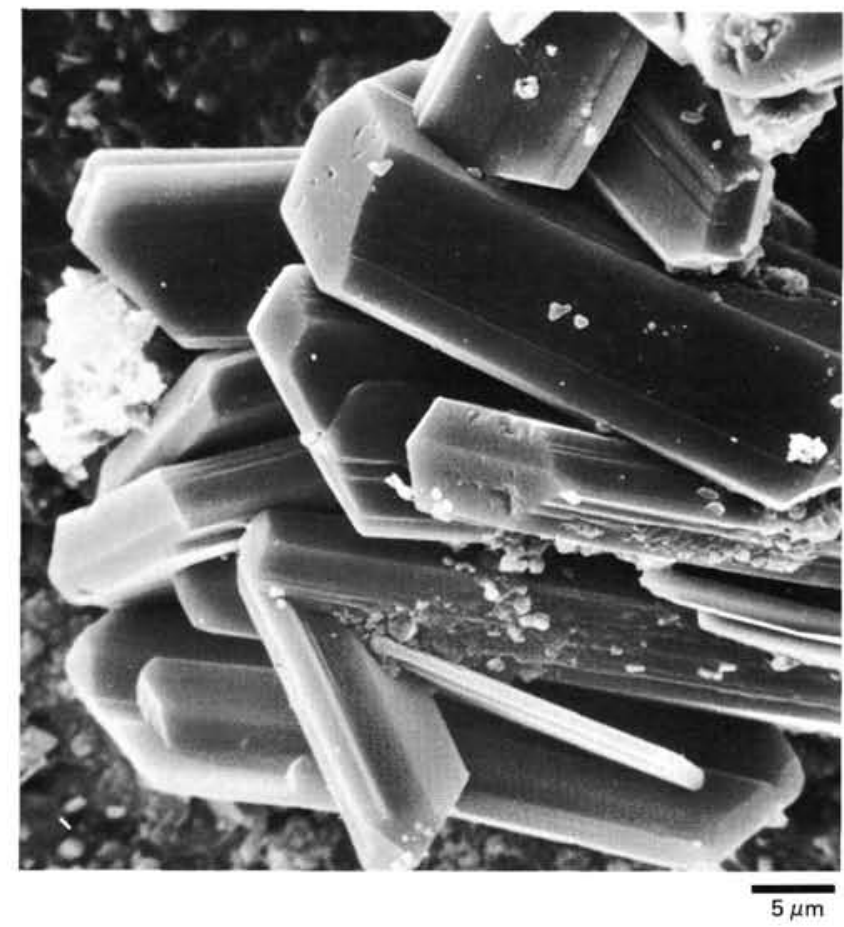

Figure 15. Monoclinic clinoptilolite crystal cluster in black claystones, SEM micrograph, Sample 386-43-2, $139 \mathrm{~cm}$.

of phillipsite in the calcareous ooze interbeds results from the lack of glass in such units.

Although zeolite genesis is controlled by multivarient factors, a general correlation has been demonstrated between the silica content of the parent glass and the type of zeolite produced by alteration. Basaltic glass tends to alter to analcite and low-silica zeolites like phillipsite (Murray and Renard, 1891; Norin, 1958; Zen, 1959; Coombs et al., 1959), whereas rhyolitic glass tends to yield the more siliceous clinoptilolite phase (Deffeyes, 1958, 1959; Gibbons et al., 1960; Hinrichs and Orkild, 1961; Moiola, 1964a, b; Robinson, 1964; Hay, 1964, 1966; Hoover and Shepard, 1965). Only Bramlette and Posjnak (1933) and Coombs (1954) document the occurrence of clinoptilolite as an alteration product of marine basaltic vitric tuffs. Thus, as the New England seamounts are the product of alkali-basaltic volcanism (Houghton, 1975; Houghton, this volume), it is considered unlikely that the occurrence of clinoptilolite in these volcaniclastic sediments is due to alteration of vitric material originating from the seamounts.

An explanation for the clinoptilolite distribution in these beds arises from its association with alkali feldspar, cristobalite, and montmorillonite in spherulitic aggregates. The aggregates appear to fall into two distinct groups: those containing high sanidine and those bearing orthoclase or no feldspar at all. The former include spherulites of strongly corroded, radiating lath-shaped high-temperature sanidine encrusted with blades of clinoptilolite. Whereas the thermodynamics of the stability of these two minerals in the marine environment is open to question, the association suggests that alteration of the high sanidine produced the clinoptilolite halo. A possible reaction is suggested below:

$$
\begin{aligned}
& 2(\mathrm{~K}, \mathrm{Na})\left(\mathrm{AlSi}_{3} \mathrm{O}_{8}\right)+6 \mathrm{H}_{2} \mathrm{O}+\mathrm{SiO}_{2} \\
= & \left(\mathrm{Ca}, \mathrm{Na}_{2}, \mathrm{~K}_{2}\right)\left(\mathrm{Al}_{2} \mathrm{Si}_{7} \mathrm{O}_{18}\right) \cdot 6 \mathrm{H}_{2} \mathrm{O}
\end{aligned}
$$

High Sanidine + Water + Quartz $=$ Clinoptilolite

Clinoptilolite aggregates bearing orthoclase cores or crusts apparently represent a different, perhaps later, history. Evidence is inconclusive whether the orthoclase is authigenic or diagenetic. Authigenic potassium feldspars are common in marine sediments (Mellis, 1960; Mathews, 1962) and may form by reaction of clay minerals in a wide variety of sedimentary rocks (Reynolds, 1929; Gruner and Theil, 1937; Baskin, 1956). Such feldspar in the presence of excess silica may alter to clinoptilolite within a narrow basic $p \mathrm{H}$ range (Hay, 1966). Alternatively, orthoclase may form by dehydration of clinoptilolite (Weiss, 1954). Under acid conditions, zeolites may be thermodynamically unstable in most sediments, as they clearly are in many laboratory experiments (Ellis and Fyfe, 1957; Koizumi and Roy, 1958; Coombs et al., 1959). Feldspar cores would favor the former explanation and crusts the latter. The occurrence of both morphologies makes differentiation between these two mechanisms in these units impossible; however, operation of both contra-reactions in the same bed is improbable.

At Site 385, spherulitic clinoptilolite comprises up to 20 per cent of sediment in the zeolitic silty clay unit.

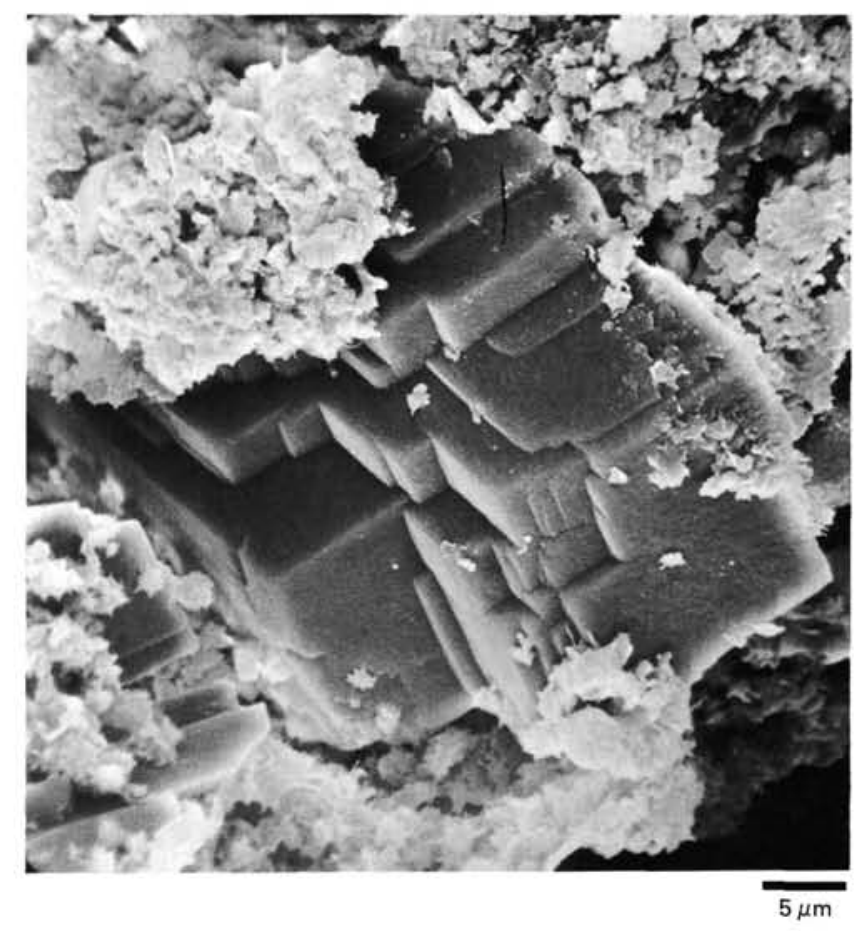

Figure 16. SEM micrograph of a chabazite rhombohedron in black claystones, Sample 386-42-2, $102 \mathrm{~cm}$. 
High clinoptilolite concentrations in this unit reflect high concentrations of disordered cristobalite and opal and increased illite:montmorillonite ratios. Stonecipher (1976) has suggested that the conversion of montmorillonite to illite in marine sediments could supply some of the silica necessary for clinoptilolite formation. As montmorillonite is more siliceous than illite, the clay mineral conversion would result in an increase in the $\mathrm{Si} / \mathrm{Al}$ ratio of the interstitial fluid due to release of silica by the montmorillonite and the uptake of $\mathrm{Al}$ by the newly formed illite. Experiments suggest that the presence of carbonate accelerates this conversion (Lancelot, 1973), and carbonate is readily available above and below the zeolitic silty clay unit on Vogel Seamount. Despite the observed correlation between silica indicators and clinoptilolite concentrations in this sediment, we feel that such an additional source of silica is probably unnecessary to drive a zeolite reaction such as the sanidine-to-clinoptilolite reaction proposed above, as pore water is nearly always saturated in silica (Edmond, 1974).

Feldspathic silty clay and variegated feldspathic silty claystone units on Nashville are characteristically low in zeolites. Concentrations which do occur probably support an alkali feldspar conversion to clinoptilolite as discussed above. Local concentrations of phillipsite and analcite at the base of the claystone probably represent contamination from the underlying basaltic breccia.

Stonecipher (1976) noted the preferred association of clinoptilolite rather than phillipsite with calcareous sediments. The zeolite distribution within the marly ooze and clay of Site 385 is consistent with this relationship. Despite Rex's (1967) claim that phillipsite, at least, is stable in contact with seawater for many millions of years, the irregular nature of clinoptilolite crystals in this unit suggests dissolution may have affected them.

In spite of a large amount of altered ash, the vitric silty clay and clay unit on Vogel Seamount is conspicuously depleted in zeolites. Phillipsite is absent, and clinoptilolite only reaches 1 per cent. The highest concentrations of clinoptilolite correlate with beds relatively enriched in silica and montmorillonite. Venkatarathnam and Biscaye (1971) have noted that these conditions may be sufficient to promote the formation of this siliceous zeolite in some basaltic terrains. However, the total absence of phillipsite from this vitric zone suggests the original ash may have been more silicic than the basaltic emanations of the New England Seamounts. As ash may be spread worldwide by atmospheric winds (Ninkovich and Robertson, 1975), an outside rhyolitic source is possible.

The underlying vitric clayey silt displays a similar zeolite character at its upper levels but is strongly (up to 3 per cent) enriched in phillipsite at its base. A basaltic source region, like that for its underlying volcaniclastic breccias, is probable.

The volcaniclastic silty sands, sandstones, and breccias representing the deepest recovery at Sites 382 and 385 show essentially identical sedimentological and zeolitic character. Basaltic lapilli within these units yield both clinoptilolite and phillipsite. Clinoptilolite is exclusively associated with spherulites surrounding partly to completely altered sanidine. These pseudoamygdules suggest sanidine was a phenocryst phase in some represented types of basalt (see Houghton, this volume), but that the feldspar was susceptible to alteration. Removal of these spherulites by weathering of the surrounding basalt could prove a source for the mineral balls occurring stratigraphically higher in the sections.

Phillipsite occurs as vesicle fillings, groundmass alterations, and cement within these coarse volcaniclastic sediments. Simple alteration of basaltic glass and basic volcanic debris such as montmorillonite is the probable origin of this zeolite occurrence. Rare zones of selvage on some of the basaltic lapilli clasts bearing phillipsite support this relationship. The occurrence of "fossil" unfilled shard cavities in otherwise completely zeolitized regions indicates that this glass reacts to form phillipsite as a solution phenomenon as suggested by Deffeyes (1959) and not as a process of devitrification or solid-state hydration.

Site 386 on the central Bermuda Rise is generally characteristic of marginal sea floor except where turbidites introduce the volcanic effect of Bermuda. Surface marly nanno ooze and brown clay as well as the underlying greenish gray hemipelagic clay and nanno ooze are generally devoid of zeolites. Local concentrations of phillipsite occur in montmorillonite-rich beds, suggesting that clay may be the framework source.

A down-core sequence of turbidites displays considerable zeolite diversity, however. The calcareous turbidite unit is free from zeolites at its carbonate-rich upper and lower margins but contains both phillipsite and clinoptilolite in its montmorillonite-rich clay interior. This clay mineral may serve as a precursor for either or both of these zeolites. Their distribution fails to suggest separate origins for these zeolites.

The underlying volcaniclastic turbidites reflect their basaltic character by bearing phillipsite-analcite but no clinoptilolite alterations. Commonly associated basaltic glass shards serve as a likely source material.

Zeolites are generally absent from the siliceous turbidites and calcareous turbidites completing that section. Trace amounts of phillipsite in the latter unit may have originated from the abundant montmorillonite, but no source relation is demonstrated.

The pelagic claystones and mudstones constituting the remainder of the stratigraphic section at Site 386 have zeolite distributions typical of those reported previously from North Atlantic sediments. The zeolite family in the cherty claystone unit which lies immediately beneath the turbidite sequence is represented by up to 6 per cent clinoptilolite. The mineral's clear association with recrystallized radiolarians and disordered cristobalite and opal suggests it derived its silica from these sources. The absence of clinoptilolite within carbonate-rich layers of this unit suggests carbonate may either inhibit the authigenic growth of clinoptilolite in siliceous beds or dilute constituent zeolite- 
producing components. The relative depletion of clinoptilolite in the underlying radiolarian mudstone may also be due to the unit's increased carbonate component. Since Stonecipher (1976) demonstrated a general correlation between clinoptilolite and calcareous sediments, the indicated suggestion is curious.

In the red claystone unit, the upper part of the section is relatively enriched in carbonate and mica/ illite and devoid of zeolite. In the lower part, dominance of montmorillonite in the clay mineral fraction and cristobalite over dolomite combine to result in the formation of significant clinoptilolite. The single occurrence of harmotome is unexplained; however, its encrustation with phillipsite is consistent with observations by Arrhenius and Bonatti (1965) that it represents the earliest alteration of basaltic glass.

The environment which produced the thick black claystone unit in the western North Atlantic was apparently not conducive to the formation of zeolites. Clinoptilolite and rare chabazite occur only in carbonate-poor radiolarian sand interbeds. As these sands are regarded as detrital (McCave, this volume), these zeolites may possibly also be of detrital origin.

Rare phillipsite observed in the recovered basalt at Site 386 is always in association with glass or montmorillonite, suggesting that they serve as parents for this alteration product.

\section{CHEMISTRY}

Electron microprobe analyses of the various zeolite minerals in the units discussed are presented in Tables 2 through 4 and schematically represented in Figures 17 through 19. In general, the compositions of individual zeolite minerals at a single site tend to show only slight variation. The major constituent elements and units of $\mathrm{Si}, \mathrm{Al}, \mathrm{K}$, and $\mathrm{H}_{2} \mathrm{O}$ remain relatively constant, whereas $\mathrm{Na}, \mathrm{Ba}$, and especially $\mathrm{Mg}$ and $\mathrm{Ca}$ display considerably greater variability.

Phillipsite commonly displays complex chemical zonations. The compositions presented represent total crystal averages. Sedimentary phillipsites are seen to be slightly more siliceous and more potassic than their counterparts in the volcaniclastic units. These chemical differences may be due in part to the higher potassium content of most sedimentary montmorillonites as compared with fresh volcanic derivatives (Copeland et al., 1971). As noted by Sheppard et al. (1970), the Si/Al ratios of the phillipsite-harmotome series are between 2.3 and 2.8. Clinoptilolite compositions, on the other hand, are seen to vary little throughout the holes save a possible slight decrease in potassium down core. This decrease may possibly be due to the effects of a clay mineral transformation. An almost steady decrease of montmorillonite is paralleled by a similar increase in illite. This illite is suggested to have originated from montmorillonite by compaction and uptake of potassium. This process would have decreased the potassium content of the interstitial solutions, and hence less potassium was available for clinoptilolite formation (Rothe, in preparation).

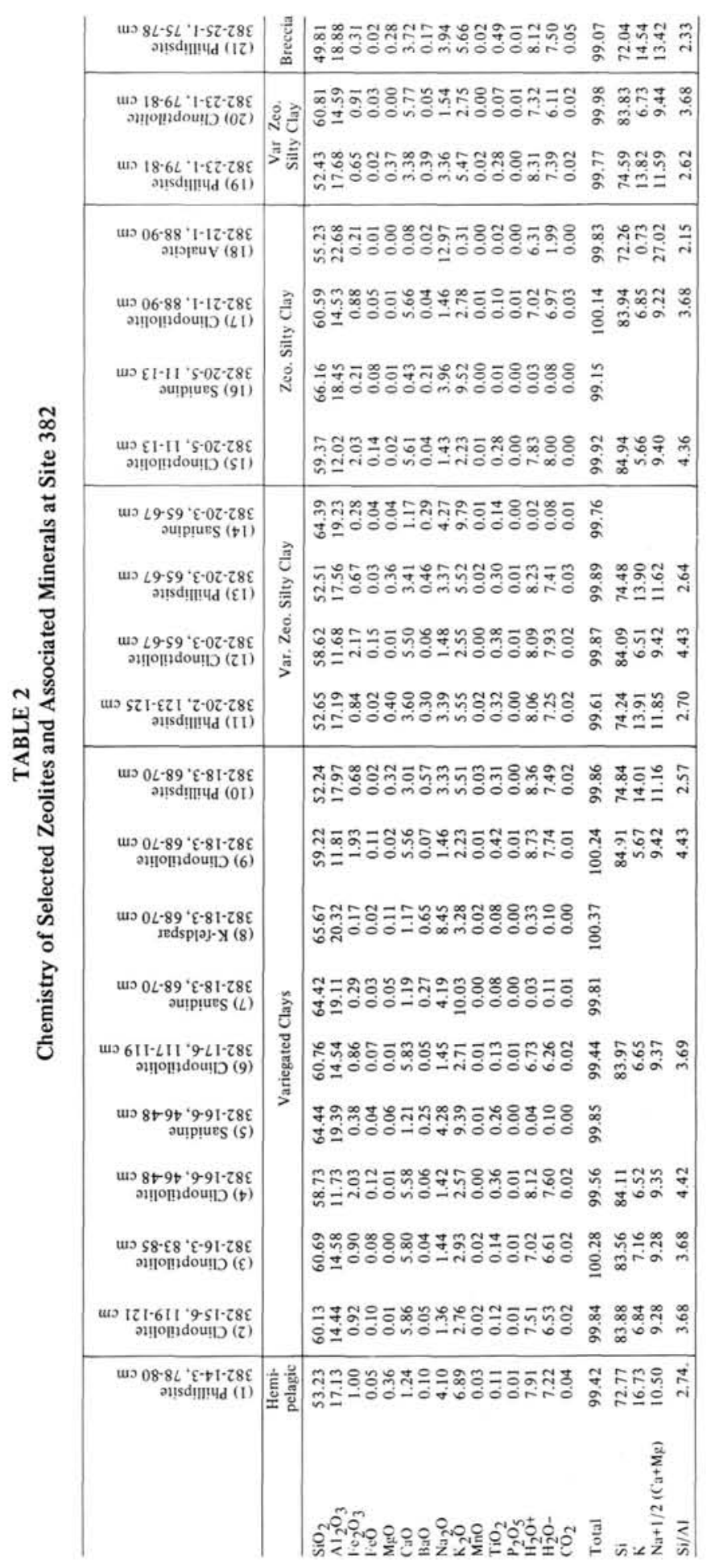


TABLE 3A

Major Element Chemistry of Selected Zeolites and Associated Minerals at Site 385

\begin{tabular}{|c|c|c|c|c|c|c|c|}
\hline & 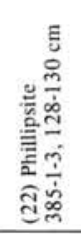 & 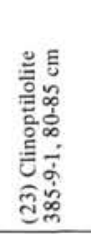 & 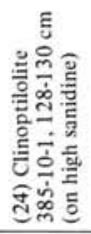 & 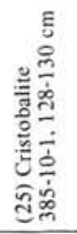 & 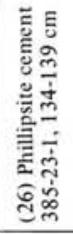 & 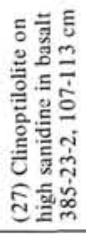 & 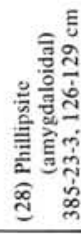 \\
\hline & $\begin{array}{c}\text { Hemi- } \\
\text { pelagic } \\
\text { Clay }\end{array}$ & \multicolumn{3}{|c|}{ Zeo. Silty Clay } & \multicolumn{3}{|c|}{ Breccia } \\
\hline $\mathrm{SiO}_{2}$ & 52.58 & 60.70 & 61.58 & 98.35 & 46.07 & 59.86 & $\begin{array}{l}43.34 \\
23.21\end{array}$ \\
\hline $\mathrm{Al}_{2} \mathrm{O}_{3}$ & 16.87 & 14.56 & 11.71 & 0.32 & 22.61 & 12.35 & 23.21 \\
\hline $\mathrm{Fe}_{2} \mathrm{O}_{3}$ & 1.02 & 1.02 & 2.36 & 0.00 & 0.22 & 2.42 & 0.96 \\
\hline $\mathrm{Fe}$ & 0.21 & 0.18 & 0.17 & 0.52 & 0.03 & 0.08 & 0.05 \\
\hline $\mathrm{Mg}$ & 0.38 & 0.0 & 0.02 & 0.01 & 0.05 & 0.09 & 0.03 \\
\hline $\mathrm{Ca}$ & 1.43 & 5.81 & 5.55 & 0.65 & 7.16 & 5.12 & 3.09 \\
\hline $\mathrm{Ba}$ & n.d. & $\mathrm{n}$. & n.d. & n.d. & n.d. & n.d. & n.d. \\
\hline $\mathrm{Na}$ & 5.24 & 1.4 & 1.44 & 0.02 & 2.04 & 1.17 & 4.62 \\
\hline $\mathrm{K}_{2} \mathrm{O}$ & 6.13 & 2.72 & 1.02 & 0.01 & 5.63 & 2.59 & 6.87 \\
\hline $\mathrm{MnO}$ & 0.05 & 0.02 & 0.01 & 0.00 & 0.0 & 0.03 & 0.02 \\
\hline $\mathrm{TiC}$ & 0.36 & 0.16 & 0.41 & 0.07 & 0.58 & 0.22 & 0.18 \\
\hline $\mathrm{P}_{2}$ & 0.00 & 0.00 & 0.00 & 0.00 & 0.01 & 0.01 & 0.01 \\
\hline $\mathrm{H}_{2} \mathrm{O}+$ & 7.07 & 7.71 & 8.30 & 0.04 & 7.56 & 8.78 & 9.49 \\
\hline $\mathrm{H}_{2} \mathrm{O}-$ & 6.99 & 6.10 & 7.43 & 0.00 & 6.63 & 7.02 & 7.63 \\
\hline $\mathrm{CO}_{2}$ & 0.10 & 2.02 & 0.02 & 0.00 & 0.03 & 0.06 & 0.03 \\
\hline Total & 99.87 & 100.16 & 100.02 & 99.99 & 98.67 & 99.80 & 99.40 \\
\hline $\mathrm{Si}$ & 71.91 & 83.96 & 88.05 & & 71.08 & 85.15 & 66.43 \\
\hline K & 14.89 & 6.69 & 2.59 & & 15.42 & 6.54 & 18.69 \\
\hline $\mathrm{Na}+1 / 2(\mathrm{Ca}+\mathrm{Mg})$ & 13.19 & 9.35 & 9.36 & & 13.50 & 8.31 & 14.89 \\
\hline $\mathrm{Si} / \mathrm{Al}$ & 2.75 & 3.68 & 4.64 & & 1.80 & 4.28 & 1.65 \\
\hline
\end{tabular}

TABLE 3B

Trace Element Chemistry of Selected Zeolites and Associated Minerals at Site 385

\begin{tabular}{|c|c|c|c|c|c|c|c|}
\hline & 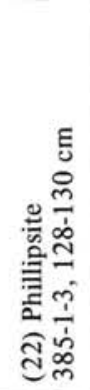 & 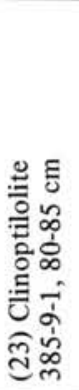 & 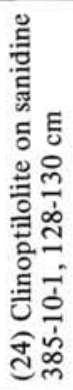 & 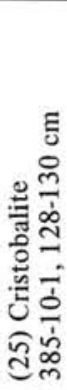 & 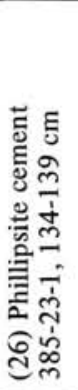 & 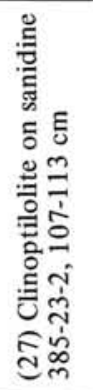 & 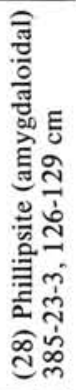 \\
\hline & $\begin{array}{c}\text { Hemi- } \\
\text { pelagic } \\
\text { Clay }\end{array}$ & \multicolumn{3}{|c|}{ Zeo. Silty Clay } & \multicolumn{3}{|c|}{ Breccia } \\
\hline $\mathrm{Nb}$ & 0 & 2 & 3 & 0 & 0 & 3 & 0 \\
\hline Y & 0 & 0 & 0 & 0 & 0 & 0 & 0 \\
\hline $\mathrm{Sr}$ & 3250 & 6467 & 6050 & 4 & 3510 & 6115 & 3100 \\
\hline $\mathrm{Rb}$ & 13 & 3 & 7 & 0 & 8 & 2 & 0 \\
\hline $\mathrm{Zr}_{\mathrm{r}}$ & 0 & 0 & 0 & & 3 & 0 & 5 \\
\hline $\mathrm{Ba}$ & n.d. & 2400 & 1800 & n. & 1200 & n.d. & 390 \\
\hline
\end{tabular}

\section{CONCLUSIONS}

The distribution of phillipsite and clinoptilolite at Sites 382,385 , and 386 suggests that the occurrence of these zeolites is apparently controlled by gross sediment composition. Phillipsite is the dominant zeolite in sediment with an appreciable volcanic and/or montmorillonite component. Analcite appears only in units with extremely high volcanic fractions. Clinoptilolite is the dominant zeolite in siliceous sediments, especially those rich in cristobalite and/or radiolarians, and in sediments relatively rich in alkali feldspar. High carbonate content appears to either prohibit zeolite formation or promote its dissolution. Extensive pitting of phillipsite crystals in Recent calcareous ooze on Vogel Seamount suggests that dissolution may be operative.

A general relationship between the occurrence of these sediment types and bathymetry also exists. Volcanogenic sediments abound only in the vicinity of seamounts or volcanic islands. Thus, Young (1939) and others have observed the relationship between phillipsite occurrences in surface sediments and seamounts, whereas the zeolites in the bulk of the North Atlantic sediments are generally dominated by clinoptilolite.

The major element compositions of the phillipsites and clinoptilolites sampled display remarkably little variation, despite diverse host sediments. The only systematic chemical variation observed is the tendency of sedimentary phillipsites to be slightly more silicic and potassic than their volcanogenic counterparts. This compositional consistency supports the limitations of sources suggested.

\section{ACKNOWLEDGMENTS}

Special thanks are extended to A. Parkes of the electron microprobe facility at M.I.T., M. Gastner of the SEM facility and R. Koch of the XRD laboratory at the University of Heidelberg, for assistance with analytical techniques. Further laboratory facilities were kindly provided by G. Müller at the Institut für Sedimentforschung of Heidelberg University. The authors also profited extensively from critical discussion with G. Thompson, R. L. Hay, and F. A. Mumpton. The reviews of J. Edmond and D. A. Johnson were also greatly appreciated. This is Contribution No. 3849 of the Woods Hole Oceanographic Institution. Financial support from the Deutsche Forschungsgemeinschaft (Grant no. RO 278/6) is acknowledged.

\section{REFERENCES}

Arrhenius, G., 1963. Pelagic sediments. In Hill, M. N. (Ed.), The sea: New York (Wiley-Interscience), v. 3, p. 655-727.

Arrhenius, G. and Bonatti, E., 1965. Neptunism and vulcanism in the ocean. In Sears, M. (Ed.), Progress in oceanography: London (Pergamon), p. 7-22.

Baskin, Y., 1956. A study of authigenic feldspars, J. Geol., v. 64, 132-155.

Biscaye, P., 1964. Mineralogy and sedimentation of deep-sea sediment fine fraction in the Atlantic and adjacent seas and oceans, Ph.D. Thesis, Yale University, New Haven.

Bonatti, E., 1963. Zeolites in Pacific pelagic sediments, N.Y. Acad. Sci. Trans. II, v. 25, p. 938-948.

Bramlette, M. N. and Posjnak, E., 1933. Zeolitic alteration of pyroclastics, Am. Mineralogist, v. 18, p. 167-171.

Coombs, D. S., 1954. The nature and alteration of some Triassic sediments from Southland, New Zealand, Roy. Soc. New Zealand Trans., v. 82, p. 65-109.

Coombs, D. S., Ellis, A. J., Fyfe, W. S., and Taylor, A. M., 1959. The zeolite facies, with comments on the interpretation of hydrothermal syntheses, Geochim. Cosmochim. Acta, v. 17 , p. 53-107.

Copeland, R. A., Frey, F. A., and Wones, D. R., 1971. Origin of clay minerals in a Mid-Atlantic Ridge sediment, Earth Planet. Sci. Lett., v. 10, p. 186-192. 
TABLE 4

Chemistry of Selected Zeolites and Associated Minerals at Site 386

\begin{tabular}{|c|c|c|c|c|c|c|c|c|c|c|c|c|c|c|c|c|c|c|c|c|c|}
\hline & 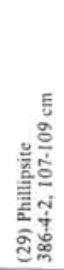 & 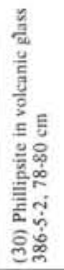 & 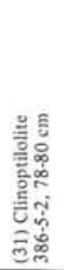 & 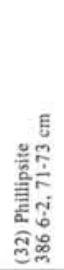 & 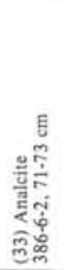 & 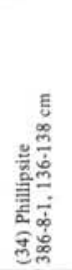 & 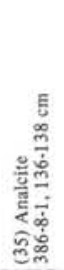 & 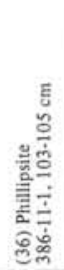 & 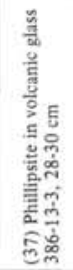 & 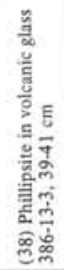 & 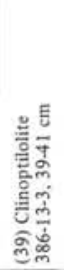 & 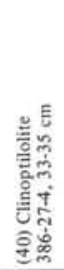 & 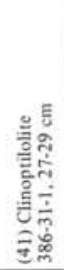 & 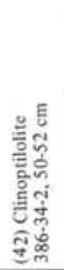 & 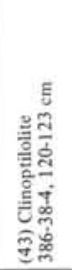 & 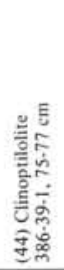 & 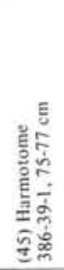 & 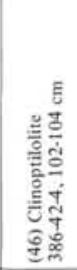 & 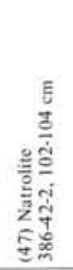 & 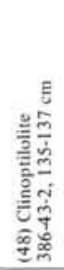 & 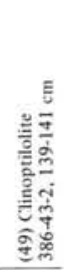 \\
\hline & $a$ & \multicolumn{7}{|c|}{ Volcaniclastic Turbidites } & \multicolumn{2}{|c|}{ b } & \multicolumn{3}{|c|}{ Cherty Claystones } & c & \multicolumn{3}{|c|}{ Red claystone } & \multicolumn{4}{|c|}{ Black Clays } \\
\hline $\mathrm{SiO}_{2}$ & 55.03 & 49.46 & 60.87 & 55.29 & 55.35 & 55.17 & 55,36 & 55.21 & 49.36 & 49.30 & 49.30 & 61.38 & 61.42 & 61.52 & 60.78 & 60.79 & 45.15 & 61.75 & 45.18 & 61.63 & 61.66 \\
\hline $\mathrm{Al}_{2} \mathrm{O}_{3}$ & 17.27 & 18.79 & 14.62 & 17.28 & 22.59 & 17.21 & 22.62 & 17.32 & 18.75 & 18.87 & 18.77 & 14.31 & 14.38 & 13.86 & 14.72 & 14.62 & 16.05 & 11.89 & 26.84 & 12.02 & 11.97 \\
\hline $\mathrm{I}_{2} \mathrm{CO}_{3}$ & 0.73 & 0.21 & 0.49 & 0.51 & 0.17 & 0.50 & 0.15 & 0.56 & 0.11 & 0.09 & 0.23 & 0.22 & 0.51 & 0.31 & 0.25 & 0.54 & 0.16 & 0.28 & 0.08 & 0.11 & 0.17 \\
\hline $\mathrm{FeO}$ & 0.06 & 0.02 & 0.05 & 0.03 & 0.03 & 0.03 & 0.03 & 0.04 & 0.01 & 0.01 & 0.02 & 0.02 & 0.06 & 0.03 & 0.03 & 0.08 & 0.01 & 0.01 & 0.00 & 0.02 & 0.01 \\
\hline $\mathrm{MpO}$ & 0.54 & 0.08 & 0.01 & 0.68 & 0.02 & 0.58 & 0.03 & 0.60 & 0.07 & 0.08 & 0.04 & 0.00 & 0.01 & 002 & 0.01 & 0.00 & 0.27 & 0.02 & 0.01 & 0.03 & 0.02 \\
\hline $\mathrm{CaO}$ & 0.50 & 5.17 & 5.83 & 0.56 & 0.05 & 0.52 & 0.05 & 0.55 & 5.22 & 5.3. & 6.07 & 5.79 & 5.86 & 5.92 & 5.82 & 5.78 & 0.14 & 5.93 & 0.35 & 5.91 & 5.91 \\
\hline $\mathrm{BaO}$ & 0.07 & 4.06 & 0.00 & 0.06 & 0.03 & 0.07 & 0.02 & 0.07 & 1.25 & 3.2 & 4.02 & 0.0 & 0.0 & 0.02 & 0.00 & 0.00 & 19.98 & 0.00 & 0.04 & 0.00 & 0.02 \\
\hline $\mathrm{Na}_{2} \mathrm{O}$ & 4.03 & 4.31 & 1.54 & 4.09 & 13.00 & 4.05 & 12.98 & 4.10 & 4.09 & 4.31 & 0.61 & 1.48 & 1.46 & 1.44 & 1.56 & 1.56 & 1.09 & 1.38 & 16.94 & 1.44 & 1.40 \\
\hline $\mathrm{K}_{2} \mathrm{O}$ & 7.00 & 5.08 & 2.69 & 6.89 & 0.36 & 6.92 & 0.36 & 7.0 & 5.89 & 5.5 & 2.15 & 2.7 & 2.7 & 2.7 & 2.71 & & 1.87 & & 0.54 & & 2.55 \\
\hline $\mathrm{MnO}$ & 0.02 & 0.03 & 0.01 & 0.02 & 0.00 & 0.02 & 0.01 & 0.01 & 0.02 & 0.01 & 0.07 & 0.01 & 0.01 & 0.00 & 0.01 & 0.0 & 0.02 & 0.05 & 0.0 & 0.03 & 0.03 \\
\hline TiO & 0.08 & 0.06 & 0.00 & 0.02 & 0.01 & 0.01 & 0.00 & 0.02 & 0.00 & 0.0 & 0.04 & 0.00 & 0.00 & 0.00 & 0.00 & 0.0 & 0.14 & 0.04 & 0.00 & 0.03 & 0.02 \\
\hline $\mathrm{P}_{2} \mathrm{O}_{5}^{2}$ & 0.00 & 0.00 & 0.01 & 0.00 & 0.00 & 0.00 & 0.00 & 0.00 & 0.00 & 0.00 & 0.02 & 0.00 & 0.00 & 0.00 & 0.00 & 0.00 & 0.00 & 0.00 & 0.00 & 0.00 & 0.00 \\
\hline $\mathrm{H}_{2} \mathrm{O}+$ & 7.49 & 8.13 & 7.06 & 7.18 & 5.77 & 7.41 & 6.32 & 7.32 & 8.31 & 7.32 & 10.29 & 7.4 & 7.3 & 7.28 & 7.57 & 7.31 & 11.73 & 8.31 & 8.51 & 8.39 & 8.56 \\
\hline $\mathrm{H}_{2} \mathrm{O}-$ & 6.81 & 4.38 & 6.33 & 6.61 & & 7.12 & 1.73 & 6.6 & 7.04 & 5. & 8.15 & 6.5 & 5.8 & 6.09 & 6.4 & & & & 1. & 7.50 & 7. \\
\hline $\mathrm{CO}_{2}$ & 0.05 & 0.01 & 0.01 & 0.02 & 0.00 & 0.01 & 0.01 & 0.01 & 0.00 & 0.00 & 0.01 & 0.00 & 0.01 & 0.02 & 0.00 & 0.00 & 0.01 & 0.02 & 0.00 & 0.03 & 0.02 \\
\hline Total & 99.68 & 99.79 & 99.52 & 99.24 & 99.33 & 99.62 & 99.67 & 99.49 & 100.12 & 99.51 & 99.79 & 99.95 & 99.65 & 99.29 & 99.92 & 99.42 & 99.64 & 100.12 & 99.78 & 99.73 & 99.99 \\
\hline $\mathrm{Si}$ & 73.76 & 71.34 & 83.90 & 73.83 & 72.18 & 73.92 & 72.21 & 73.62 & 70.16 & 70.37 & 83.93 & 84.01 & 84.02 & 83.94 & 83.78 & 83.73 & 89.44 & 84.53 & 61.63 & 84.36 & 84.52 \\
\hline $\mathrm{K}_{\mathrm{N} u+1 / 2,(\mathrm{Cu}+\mathrm{Mg})}$ & $\begin{array}{r}16.66 \\
9.58\end{array}$ & $\begin{array}{l}13.02 \\
15.64\end{array}$ & $\begin{array}{l}6.58 \\
9.53\end{array}$ & $\begin{array}{r}16.34 \\
9.83\end{array}$ & $\begin{array}{r}0.84 \\
26.98\end{array}$ & $\begin{array}{r}16.45 \\
9.63\end{array}$ & $\begin{array}{r}0.84 \\
26.95\end{array}$ & $\begin{array}{r}16.63 \\
9.75\end{array}$ & $\begin{array}{l}14.87 \\
14.96\end{array}$ & $\begin{array}{l}13.96 \\
15.67\end{array}$ & $\begin{array}{l}6.48 \\
9.58\end{array}$ & $\begin{array}{l}6.71 \\
9.28\end{array}$ & $\begin{array}{l}6.67 \\
9.31\end{array}$ & $\begin{array}{l}6.74 \\
9.31\end{array}$ & $\begin{array}{l}6.64 \\
9.58\end{array}$ & $\begin{array}{l}6.75 \\
9.52\end{array}$ & $\begin{array}{l}6.57 \\
3.98\end{array}$ & $\begin{array}{l}6.24 \\
9.23\end{array}$ & $\begin{array}{r}1.31 \\
37.06\end{array}$ & $\begin{array}{l}6.30 \\
9.34\end{array}$ & $\begin{array}{l}6.22 \\
9.27\end{array}$ \\
\hline Si /AI & 2.81 & 2.32 & 3.68 & 2.82 & 2.16 & 2.83 & 2.16 & 2.82 & 2.32 & 2.31 & 2.32 & 3.79 & 3.77 & 3.92 & 3.65 & 3.67 & 2.48 & 4.59 & 1.49 & 4.53 & 4.55 \\
\hline
\end{tabular}

Talcarcous turbidites

bVolcante turbidites.

'Red mudstone.

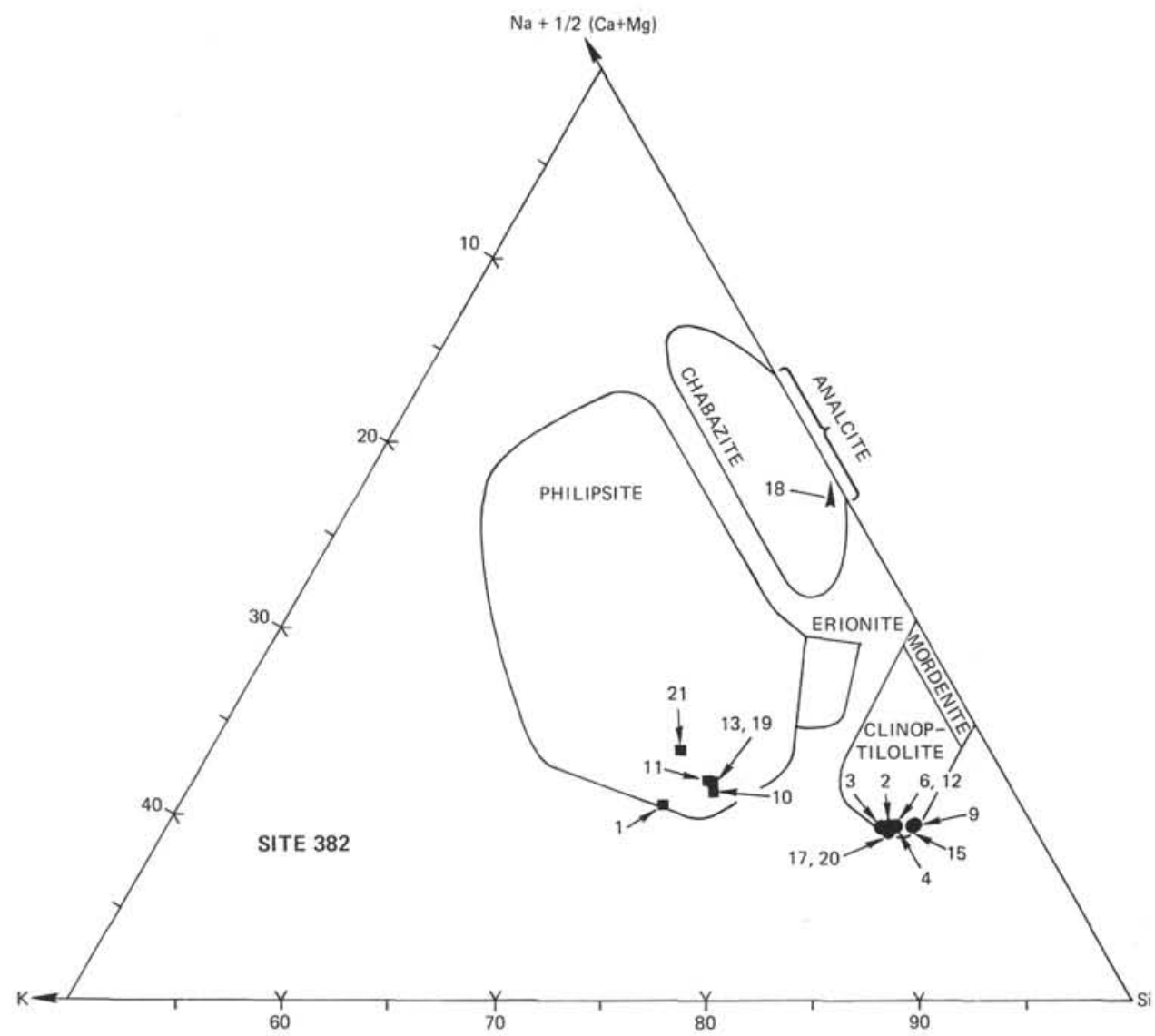

Figure 17. $\mathrm{Na}+1 / 2(\mathrm{Ca}+\mathrm{Mg})-\mathrm{K}$-Si triangular diagram of common zeolite compositions at Site 382. 


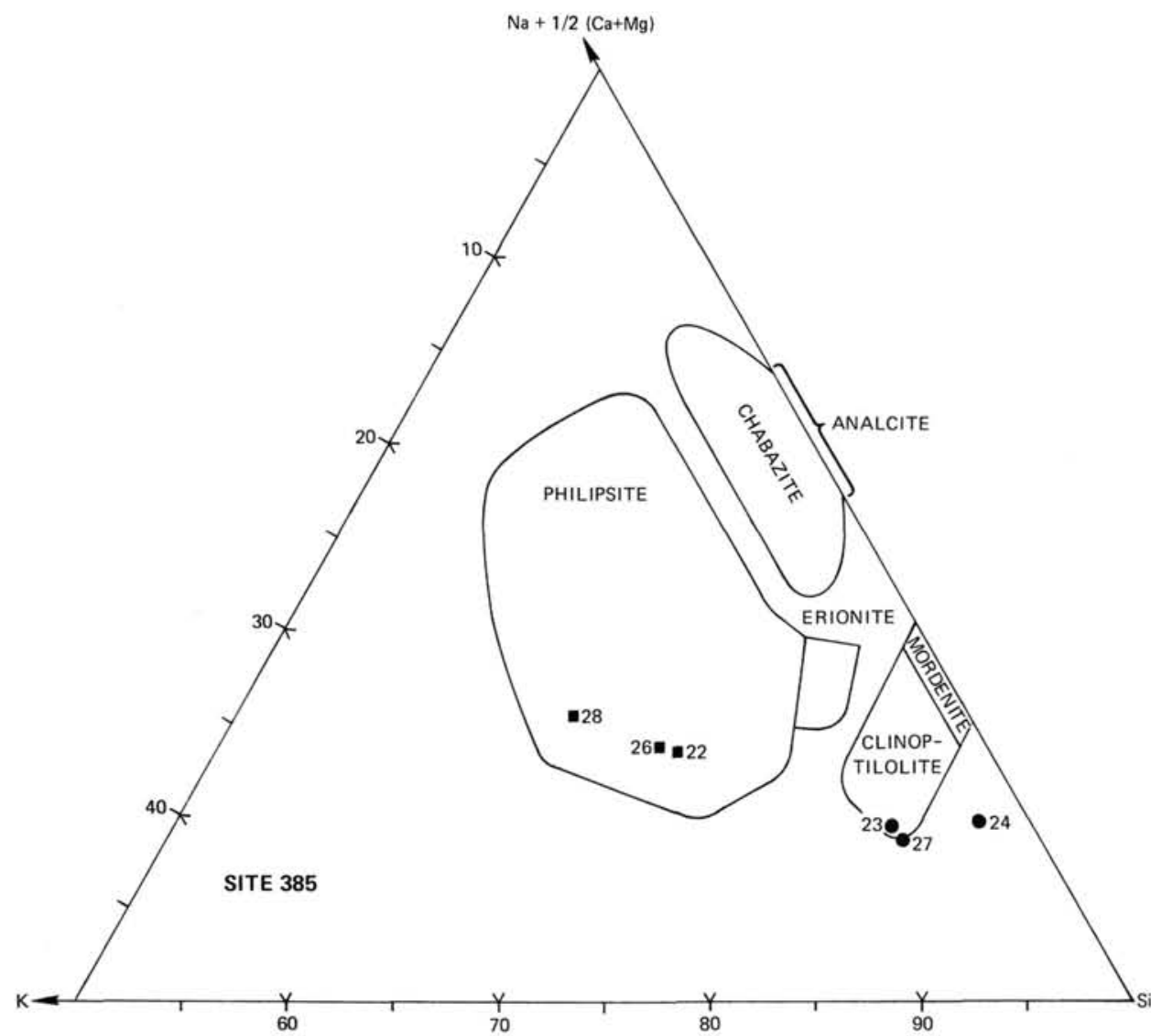

Figure 18. $\mathrm{Na}+1 / 2(\mathrm{Ca}+\mathrm{Mg})-\mathrm{K}-\mathrm{Si}$ triangular diagram of common zeolite compositions at Site 385 .

Deffeyes, K. S., 1958. Ph.D. Thesis, Princeton, New Jersey. 1959. Zeolites in sedimentary rocks, J. Sediment. Petrol., v. 29, p. 602-609.

Dekeyser, W., 1958. Examinations of cores 72 and 273. In Pettersson, H. (Ed.), Rept. Swedish Deep-Sea Exped., 1947-48, Goteborgs Kungl. Vetensk. Vitterhets-Samhalle, v. 10 , p. $34-37$.

Edmond, J. M., 1974. On the dissolution of carbonate and silicate in the deep ocean, Deep-Sea Res., v. 21 , p. 455 480.

Ellis, A. J. and Fyfe, W. S., 1957. Hydrothermal chemistry, Rev. Pure Appl. Chem., v. 7, p. 261-316.

Gibbons, A. B., Hinrichs, E. N., and Botinelly, T., 1960. The role of impermeable rocks in controlling zeolitic alteration of tuff. In Geological Survey Research, 1960, U.S. Geol. Surv. Prof. Paper 400-B, p. 473-475.

Goldberg, E. D., 1964. The oceans as a geological system, N.Y. Acad. Sci. Trans., v. 27, p. 7-19.

Goodell, H. G., 1965. The marine geology of the Southern Ocean, Contrib. 11, Sedimentology Res. Lab., Fla. State Univ.

Griffin, J. J., Windom, H., and Goldberg, E. D., 1968. The distribution of clay minerals in the world ocean, Deep-Sea Res., v. 15 , p. 433.

Gruner, J. W. and Theil, G. A., 1937. The occurrence of finegrained authigenic feldspar in shales and silts, $\mathrm{Am}$. Mineralogist, v. 22 , p. $842-846$.

Hay, R. L., 1964. Phillipsite in saline lakes and soils, Am. Mineralogist, v. 49, p. 1366-1387.

1966. Zeolites and zeolitic reactions in sedimentary rocks, Geol. Soc. Am. Spec. Paper 85, p. 1-130.
Hinrichs, E. N. and Orkild, P. P., 1961. Eight members of the Oak Spring Formation, Nevada test site and vicinity, Nye and Lincoln counties, Nevada. In Geological Survey Research, 1961, U.S. Geol. Surv. Prof. Paper 424-D, p. D96-103.

Hoover, D. L. and Shepard, A. O., 1965. Zeolite zoning in volcanic rocks of the Nevada test site, Nye Co., Nevada (abs.), Am. Mineralogist, v. 50, p. 287.

Houghton, R. L., 1975. Petrology and geochemistry of the New England Seamount chain, Ph.D. Thesis Proposal, Joint Program in Oceanography, MIT-WHOI, p. 1-20.

Koizumi, M. and Roy, R., 1958. Zeolite studies I. Synthesis and stability of the calcium zeolites, J. Geol., v. 68, p. 41-53.

Lancelot, Y., 1973. Chert and silica diagenesis in sediments from the central Pacific. In Winterer, E. L., Ewing, J. I., et al., Initial Reports of the Deep Sea Drilling Project, v. 17: Washington (U.S. Government Printing Office), p. 377-405.

Mathews, D. H., 1962. Altered lavas from the floor of the eastern North Atlantic, Nature, v. 194, p. 368-369.

Mellis, O., 1960. Gesteinsfragmente im Roten Ton des Atlantischen Ozeans: Goteborgs Kungl. Vetenskaps-och Vitterhets-Samhales Handlingar, 6th ser., pt. B, v. 8, p. 3-17.

Moiola, R. J., 1964a. Authigenic mordenite in the Esmeralda "Formation," Nevada, Am. Mineralogist, v. 49, p. 1472-1474.

1964b. Origin of authigenic silicate minerals in the Esmeralda "Formation" of western Nevada. In 


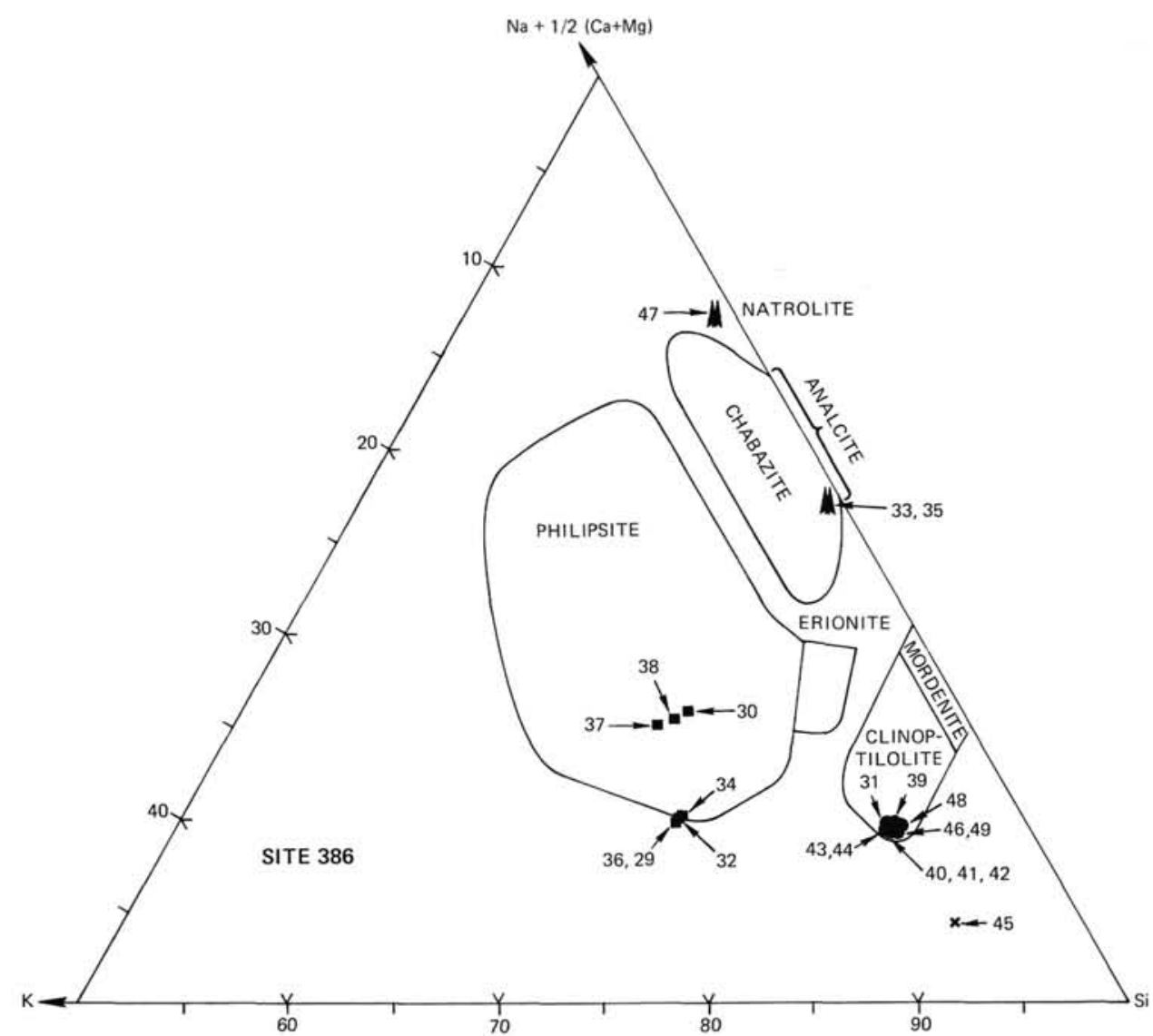

Figure 19. $\mathrm{Na}+1 / 2(\mathrm{Ca}+\mathrm{Mg})-\mathrm{K}-\mathrm{Si}$ triangular diagram of common zeolite compositions at Site 386.

Geological Society of America Abstracts for 1963, Geol. Soc. Am. Spec. Paper 76, p. 342.

Mumpton, F. A., 1960. Clinoptilolite redefined, Am. Mineralogist, v. 45, p. 351-369.

Mumpton, F. A. and Ormsby, W. C., 1976. Morphology of , zeolites in sedimentary rocks by scanning electron microscopy, Clays and Clay Min., p. 1-23.

Murray, J. and Renard, A. F., 1891. Deep sea deposits, Rept. Sci. Results Explor. Voyage HMS Challenger, 1873-1876, H.M.S.O., p. 1-525.

Ninkovich, D. and Robertson, J. H., 1975. Volcanogenic effects on the rates of deposition of sediments in the northwest Pacific Ocean, Earth Planet Sci. Lett., v. 27, p. 127-136.

Norin, E., 1958. The sediments of the central Tyrrhenian Sea. In Pettersson, H. (Ed.), Rept. Swedish Deep-Sea Exped., 1947-1948, v. 8, Sediment Cores from the Mediterranean Sea and the Red Sea, Goteborgs Kungl. Vetenkaps-och Vitterhets-Samhalle, p. 1-136.

Regnier, J., 1960. Cenozoic geology in the vicinity of Carlin, Nevada, Geol. Soc. Am. Bull., v. 71, p. 1189-1210.

Rex, R. W., 1967. Authigenic silicates formed from basaltic glass by more than 60 million years contact with seawater, Sylvania Guyot, Marshall Islands, J. Geophys. Res., v. 76, p. 195-203.

Reynolds, D. L., 1929. Some new occurrences of authigenic potash feldspars, Geol. Mag., v. 66, p. 390-399.

Robinson, P. T., 1964. Ph.D. Thesis, Univ. Calif., Berkeley.

Ross, C. S., 1928. Sedimentary analcite, Am. Mineralogist, v. 13, p. 195-197.
1941. Sedimentary analcite, Am. Mineralogist, v. 26 , p. $627-629$.

Shepard, F. P., 1973. Submarine geology: New York (Harper and Row), 3rd ed.

Sheppard, R. A., Gude, A. J., and Griffin, J. J., 1970. Chemical composition and physical properties of phillipsite from the Pacific and Indian oceans, Am. Mineralogist, v. 55 , p. $2053-2062$.

Steinfink, H., 1962. The crystal structure of the zeolite, phillipsite, Acta Cryst., v. 15, p. 644-651.

Stonecipher, S. A., 1976. Origin, distribution and diagenesis of phillipsite and clinoptilolite in deep-sea sediments, Chem. Geol., v. 17, p. 307-318.

Strunz, H., 1970. Mineralogische Tabellen, Leipzig (Akademische Verlagsgesellschaft).

Sudo, T. and Matsuoka, M., 1959. Artificial crystallization of volcanic glass to sodalite and a zeolite structure, Geochim. Cosmochim. Acta, v. 17, p. 1-5.

Turekian, K. K., 1965. Some aspects of the geochemistry of marine sediments. In Riley, J. P. and Skirrow, G. (Eds.), Chemical oceanography: London (Academic Press), v. 2, p. 81-126.

Venkatarathnam, K. and Biscaye, P. E., 1971. Zeolites from the sediments in the Indian Ocean, Geol. Soc. Am. Abstract with Programs, p. 738-739.

von Rad, U. and Rosch, H., 1972. Mineralogy and origin of clay minerals, silica and authigenic silicates in Leg 14 sediments. In Hayes, D. E., Pimm, A. C., et al., Initial Reports of the Deep Sea Drilling Project, v. 14: Washington (U.S. Government Printing Office), p. 727-752. 
Walker, G. P. L., 1960a. Zeolite zones and dike distribution in relation to the structure of the basalts of eastern Iceland, J. Geol., v. 68 , p. 515-528.

1960b. The amygdule minerals in the Tertiary lavas of Iceland. III. Regional distribution, Mineral. Mag., v. 32 , p. $503-527$.

Weiss, M. P., 1954. Feldspathized shales from Minnesota, $J$. Sediment Petrol., v. 24, p. 270-274.
Yeroshchev-Shak, V. A., 1964. Clay minerals of the Atlantic Ocean, Sov. Oceanog., v. 30, p. 90-106.

Young, J. A., 1939. Minerals from deep sea cores and surface deposits of Bermudian calcareous sediments, Am. J. Sci., v. 237 , p. $798-810$.

Zen, E-an, 1959. Mineralogy and petrography of marine bottom sediment samples off the coast of Peru and Chile, J. Sediment. Petrol., v. 29, p. 513-539. 